\title{
New ground ice maps for Canada using a paleogeographic modelling approach
}

\author{
H. Brendan O'Neill, Stephen A. Wolfe, and Caroline Duchesne \\ Geological Survey of Canada, Natural Resources Canada, 601 Booth St., Ottawa, Canada \\ Correspondence: H. Brendan O’Neill (hughbrendan.oneill@ canada.ca)
}

Received: 12 September 2018 - Discussion started: 20 September 2018

Revised: 29 January 2019 - Accepted: 1 February 2019 - Published: 5 March 2019

\begin{abstract}
Ground ice melt caused by climate-induced permafrost degradation may trigger significant ecological change, damage infrastructure, and alter biogeochemical cycles. The fundamental ground ice mapping for Canada is now $>20$ years old and does not include significant new insights gained from recent field- and remote-sensing-based studies. New modelling incorporating paleogeography is presented in this paper to depict the distribution of three ground ice types (relict ice, segregated ice, and wedge ice) in northern Canada. The modelling uses an expert-system approach in a geographic information system (GIS), founded in conceptual principles gained from empirically based research, to predict ground ice abundance in near-surface permafrost. Datasets of surficial geology, deglaciation, paleovegetation, glacial lake and marine limits, and modern permafrost distribution allow representations in the models of paleoclimatic shifts, tree line migration, marine and glacial lake inundation, and terrestrial emergence, and their effect on ground ice abundance. The model outputs are generally consistent with field observations, indicating abundant relict ice in the western Arctic, where it has remained preserved since deglaciation in thick glacigenic sediments in continuous permafrost. Segregated ice is widely distributed in fine-grained deposits, occurring in the highest abundance in glacial lake and marine sediments. The modelled abundance of wedge ice largely reflects the exposure time of terrain to low air temperatures in tundra environments following deglaciation or marine/glacial lake inundation and is thus highest in the western Arctic. Holocene environmental changes result in reduced ice abundance where the tree line advanced during warmer periods. Published observations of thaw slumps and massive ice exposures, segregated ice and associated landforms, and ice wedges allow a favourable preliminary assessment of the models, and the re-
\end{abstract}

sults are generally comparable with the previous ground ice mapping for Canada. However, the model outputs are more spatially explicit and better reflect observed ground ice conditions in many regions. Synthetic modelling products that incorporated the previous ground ice information may therefore include inaccuracies. The presented modelling approach is a significant advance in permafrost mapping, but additional field observations and volumetric ice estimates from more areas in Canada are required to improve calibration and validation of small-scale ground ice modelling. The ground ice maps from this paper are available in the supplement in GeoTIFF format.

Copyright statement. The works published in this journal are distributed under the Creative Commons Attribution 4.0 License. This license does not affect the Crown copyright work, which is re-usable under the Open Government Licence (OGL). The Creative Commons Attribution 4.0 License and the OGL are interoperable and do not conflict with, reduce or limit each other.

(C) Crown copyright 2019

\section{Introduction}

Ground ice is a key geomorphic agent in permafrost environments, and its formation is associated with characteristic landforms including ice-wedge polygons (Fraser et al., 2018; Lachenbruch, 1962); peat plateaus, palsas, and lithalsas (Laberge and Payette, 1995; Wolfe et al., 2014; Zoltai, 1972); earth hummocks (Kokelj et al., 2007b); involuted hills (Mackay and Dallimore, 1992); and pingos (Mackay, 1973). The degradation of ice-rich permafrost 
initiates geomorphic processes including thaw subsidence, slumping, active-layer detachment sliding, thaw lake development, and thermal erosion gullying (Kokelj and Jorgenson, 2013). These processes partly drive the evolution of permafrost terrain to produce the current landscape and ecological configuration and may also damage infrastructure (Jorgenson et al., 2006; Liljedahl et al., 2016; Nelson et al., 2001; Raynolds et al., 2014). The nature and distribution of ground ice controls specific processes and the impacts of thaw on permafrost terrain. For example, melt of thick relict ice may result in the formation of deep thaw lakes in flat areas (Burn, 2002; Dallimore et al., 2000) and large retrogressive thaw slumps on hillslopes (Kokelj et al., 2017). Segregated ice melt may lead to shallow pond and thaw lake development (Hopkins, 1949) and smaller thaw slumps and active-layer detachment slides on hillslopes (Burn and Lewkowicz, 1990; Lewkowicz, 2007). Ice-wedge melt may form thermokarst pits and troughs in flat terrain (Jorgenson et al., 2006; Kokelj and Jorgenson, 2013), and thermal erosion gullies on hillslopes (Fortier et al., 2007; Fraser et al., 2018).

The Permafrost Map of Canada (PMC) compiled by Heginbottom et al. (1995) remains the primary source depicting ground ice information for the entire country. The ground ice mapping has proven to be of broad utility across disciplines and is used as input for other products including thermokarst and permafrost hazard potential mapping (e.g., Nelson et al., 2001; Olefeldt et al., 2016). However, the ground ice information is now over 2 decades old and does not include newer insights into ground ice conditions from field- and remote-sensing-based studies. In addition, the map units are based on broad physiographic regions that include a variety of landscape types and surficial sediments, and thus the ground ice depiction lacks spatial detail. Given anticipated climate-driven permafrost thaw and the recent acceleration of thermokarst processes across circumpolar regions (Fraser et al., 2018; Jorgenson et al., 2006; Lantz and Kokelj, 2008; Liljedahl et al., 2016; Rudy et al., 2017), improving knowledge of ground ice conditions is of critical societal and environmental relevance. The broad aims of this paper are to (1) present a new paleogeographic approach to modelling the abundance of three ground ice types in permafrost, (2) present resulting ground ice maps for Canada, and (3) conduct a preliminary assessment of the model outputs. The specific modelling objectives are to (i) produce an improved depiction of ground ice conditions in Canada that incorporates knowledge gained from recent empirical studies, (ii) encourage the development of questions and hypotheses to guide new empirical ground ice investigations, and (iii) identify requirements to advance future modelling and mapping efforts.

\section{Background}

Ground ice information on the PMC includes qualitative estimates of the volumetric percentage of visible segregated and intrusive ice in the upper 10-20 m of permafrost (Heginbottom and Dubreuil, 1993). The relative abundance (abundant, sparse, absent) of larger ice bodies is represented separately using symbols for massive ice, ice wedges, and pingos. The map polygons were based on 141 physiographic regions (Bostock, 1970), with some subdivided based on the distribution of permafrost, resulting in 171 map units (Heginbottom and Dubreuil, 1993). The mapping was developed using a database of available ground ice observations, mostly from western Canada. Gaps were filled by assessing available geological and environmental conditions and comparing them to adjacent units or others with similar attributes (Heginbottom and Dubreuil, 1993). Ground ice conditions were then assigned to units with similar physiographic attributes. Therefore, much of the mapping in the central and eastern Arctic represents extrapolations based on conditions in the western Arctic. The ground ice information from the PMC was included in the Circum-Arctic Map of Permafrost and Ground-ice Conditions (Brown et al., 1997). While most of the original elements were maintained, some modifications were included in the circum-Arctic representation. These included the differentiation of map polygons into areas with thin $(<5-10 \mathrm{~m})$ and thick $(>5-10 \mathrm{~m})$ overburden cover (Brown et al., 1997). In general, this distinction separated the sediment-poor Canadian Shield and areas of exposed weathered bedrock from areas underlain by sedimentary rock with more extensive and thick surficial deposits. The depicted ground ice contents are generally lower in regions with thin overburden (Brown et al., 1997), but the nature and origin of surficial deposits were not explicitly considered.

The modelling approach presented here builds on that of Jorgenson et al. (2008) for recent mapping in Alaska. The authors assessed excess ice content - the volumetric ice content in excess of soil pore space - in the top $5 \mathrm{~m}$ of permafrost from various ice types, based primarily on surficial geology and permafrost distribution. The ice contents generally correspond to soil texture, with fine-grained, frostsusceptible units assigned the highest values and buried ice recognized in glacial deposits (Jorgenson et al., 2008). The influence of time and the mode of permafrost aggradation (epigenetic vs. syngenetic) on segregated and wedge ice content were also considered by differentiating old and young glacial deposits and by recognizing high ice contents in aggraded loess and re-transported colluvial sediments (Jorgenson et al., 2008). Our assessment similarly uses surficial geology as a base dataset. The $1: 5000000$ scale Surficial geology of Canada consists of 10325 polygons with an average area of about $880 \mathrm{~km}^{2}$ over Canada's landmass (Geological Survey of Canada, 2014). By comparison, the average area of the polygons on the Heginbottom et al. (1995) map 
is about $53200 \mathrm{~km}^{2}$. Thus, the surficial geology dataset is more spatially detailed and may better represent variation in conditions that control ground ice than the modified physiographic map of Bostock (1970). Modern computing, GIS software, and available digital datasets facilitate this new approach (Heginbottom, 2002).

Three common forms of ground ice in permafrost are modelled: (1) relict ice, (2) segregated ice, and (3) wedge ice, each defined specifically in Sect. 2.1. Volumetric ice abundance in the top $5 \mathrm{~m}$ of permafrost is reported qualitatively for each map unit (i.e., pixel). This depth is considered because wedge and segregated ice content is commonly highest within several metres below the permafrost table (Jorgenson et al., 2008; Pollard and French, 1980) and because increases in thaw depth caused by climate variation and surface disturbances are typically restricted within this range (Burn, 1998; Mackay, 1995). Pingos are not modelled, as they form due to local geologic and hydraulic conditions, are easily mapped from observations (Jones et al., 2012; Jorgenson et al., 2008; Mackay, 1963), and comprise a low proportion of near-surface ground ice volume even in areas where they are abundant (Pollard and French, 1980).

Rather than extrapolating field observations from northwestern Canada to similar physiographic units across the Arctic (Heginbottom et al., 1995), we model ground ice abundance using an expert-system approach built on principles developed from empirical studies relating environmental conditions to ground ice formation and preservation. The principles are formalized in a GIS using spatio-temporal datasets, and ground ice abundance for each ice type is calculated using map algebra (i.e., raster calculation). The models account for surficial geology, which regulates ground ice formation and preservation, and broadscale Holocene environmental changes including deglaciation, glacial lake and marine inundation, and paleovegetation shifts that represent climate history. The expert-system is based on logical deduction and uses numerous conceptual models (rules) that link Holocene environmental conditions and processes to ground ice abundance. These rules include the following, for example: (1) regions covered by thick glacial sediments that have remained in tundra throughout the Holocene may include preserved glacial ice; (2) significant segregated ice has accumulated in regions with fine-grained sediments; (3) ice wedges form over time, and growth rates are most rapid in cold tundra environments; (4) ground ice thaws when terrain becomes inundated by the sea or by proglacial lakes. Many of the studies and datasets key to the model development were unavailable during production of the PMC, and thus the model outputs represent an updated understanding of ground ice conditions in Canada.

\subsection{Ground ice types}

\subsubsection{Relict ice}

Here, relict ice is considered to be larger bodies or layers of ice preserved in permafrost under overburden by persistent cold-climate conditions. Relict ice may consist of either (1) buried glacier ice (French and Harry, 1988, 1990; Lorrain and Demeur, 1985; St-Onge and McMartin, 1995) or (2) intrasedimental ice formed by segregation, injection, or a combination thereof (Mackay and Dallimore, 1992; Rampton, 1988a). Buried glacier ice in Canada is predominantly found within large hummocky moraine belts and glaciofluvial deposits (Coulombe et al., 2019; Dyke and Savelle, 2000; French and Harry, 1990; Kokelj et al., 2017; Lakeman and England, 2012; Murton et al., 2005) and may consist of englacial or basal ice preserved by an overburden of ablation till or outwash (Evans, 2003). Intrasedimental ice has been identified in some regions of northern Canada (Dallimore and Wolfe, 1988; French and Harry, 1990; Fritz et al., 2011; Mackay and Dallimore, 1992; Murton, 2005; Pollard, 2000). This ice is considered to form by segregation and/or intrusion at the interface between layers of fine-grained and coarse-grained deposits during epigenetic permafrost growth (Mackay, 1971). The underlying unfrozen stratum supplies the water for ice growth. Isotopic evidence indicates that massive intrasedimental ice is commonly of glacial meltwater origin (Mackay and Dallimore, 1992). Thick ice growth may be facilitated by high pore water pressures that develop during freezing of saturated sands and gravels (pore water expulsion) or by glacial meltwater driven toward aggrading permafrost near an ice sheet margin (Konrad, 1990; Mackay and Dallimore, 1992; Rampton, 1988a). Debate remains over the origin (buried glacier ice vs. intrasedimental ice) of some ice-cored terrain in northern Canada due to the similar morphological appearance, associated surficial materials, and distribution near margins of the late-Wisconsinan Laurentide Ice Sheet (Evans, 2003). The relict ice model does not account for the localized hydraulic and stratigraphic conditions that may form intrasedimental ice, so the results should be considered representative of relict buried glacier ice, though intrasedimental ice may form locally within the same glacigenic deposits (Murton et al., 2005).

\subsubsection{Segregated ice}

Segregated ice consists of discrete ice lenses or layers that form by migration of unfrozen pore water towards a freezing front (Taber, 1929). This segregated ice consists of relatively thin ice lenses and layers that form various cryostructures and is thus differentiated from larger intrasedimental ice bodies formed by segregation and/or intrusion. Segregated ice is widely distributed in fine-grained material in Canada, whereas large intrasedimental ice bodies formed in spatially and temporally restricted proglacial settings during 
recession of the Laurentide Ice Sheet (Rampton, 1988a) or smaller ice caps (Robinson and Pollard, 1998).

Segregated ice growth results in frost heaving, a displacement of the ground surface due to the volumetric increase in the soil as ice forms (Miller, 1972). Segregated ice forms during epigenetic (downward) permafrost growth and due to annual downward water migration from the active layer into permafrost (Cheng, 1983; Mackay, 1983). Gradual ice enrichment near the top of permafrost and a rising permafrost table due to climatic cooling, organic accumulation, or sedimentation in alluvial, eolian, or colluvial sediments forms aggradational ice, resulting in an upper ice-rich "intermediate" layer found commonly in permafrost regions (French and Shur, 2010). Slow epigenetic freezing may form the segregated ice expressed as lithalsas, palsas, and peat plateaus (Allard et al., 1996; Calmels et al., 2008a; Laberge and Payette, 1995; Wolfe et al., 2014). Examples of segregated ice enrichment include the ice visible in exposures above thaw unconformities (Burn, 1988; Kokelj and Burn, 2003), in near-surface sediments of drained lake basins (Mackay and Burn, 2002a; Morse et al., 2009; O'Neill and Burn, 2012), in aggraded alluvial settings (Kokelj and Burn, 2005; Morse et al., 2009), and in loess sequences (Fortier et al., 2018; Fraser and Burn, 1997; Kotler and Burn, 2000). Segregated ice may be expressed as distinct cryofacies in polygenetic permafrost, where epigenetic permafrost growth is followed by surface sediment or organic matter accumulation and subsequent syngenetic permafrost development (e.g., French and Shur, 2010; Gilbert et al., 2018).

\subsubsection{Wedge ice}

Wedge ice develops when low winter temperatures cause the ground to contract under stress and crack (Lachenbruch, 1962). Meltwater later infills the cracks and freezes in permafrost, forming thin ice veins. Cracking in subsequent years occurs preferentially at existing ice veins because the tensile strength of the ice is lower than that of the surrounding frozen sediment (Lachenbruch, 1962). Repeated cracking, water infilling, and refreezing causes the growth of an ice wedge over time. Ice-wedge growth is thus controlled by winter temperature conditions and the time available for ice accumulation (Hamilton et al., 1983; Mackay and Burn, 2002b; Opel et al., 2018). Wedge ice may comprise a significant volume of the upper ground in permafrost areas (Kanevskiy et al., 2013; Pollard and French, 1980; Ulrich et al., 2014), and the partial thaw of ice wedges can lead to ground subsidence that spurs marked ecological changes (Fraser et al., 2018; Jorgenson et al., 2006; Liljedahl et al., 2016).

\section{Datasets and methods}

Ground ice in permafrost today is the result of past geological and environmental processes affecting its formation, preservation, and decay (Gilbert et al., 2016). Since most permafrost in the surficial geological material formed during and after the last glaciation, we model ground ice evolution over the last $17 \mathrm{kyr}$ in Canada. Ground ice formed in unglaciated terrain prior to deglaciation is thus not considered. The 1:5000000 scale Surficial geology of Canada forms the basis of the three ground ice models (Geological Survey of Canada, 2014). Surficial geology units were modified using data from the Glacial map of Canada (Prest et al., 1968) and the bedrock Geological map of Canada (Wheeler et al., 1996) to better reflect physical conditions pertinent to ground ice formation. The distribution of hummocky terrain from the Glacial map of Canada was added to the surficial dataset, as these "controlled moraine" deposits commonly host relict ground ice in permafrost regions (Dyke and Savelle, 2000; Evans, 2009; Kokelj et al., 2017), which are not adequately represented on the Surficial geology of Canada map. The surficial dataset was further modified by combining emerged nearshore and offshore glaciomarine and marine units deposited in postglacial seas, respectively, as these typically include sediments with comparable soil textures in both depositional settings (Geological Survey of Canada, 2014) and thus have similar frost susceptibility.

Areas underlain by igneous, metamorphic, and volcanic bedrock were differentiated from those underlain by sedimentary bedrock using the Geological map of Canada (Wheeler et al., 1996). Till and colluvial units from the Surficial geology of Canada map were reclassified as either fine-grained (sedimentary bedrock derived) or coarsegrained (shield bedrock derived) units to reflect characteristic differences in matrix texture controlled by bedrock source (Fulton, 1989). It can be assumed that dominantly finegrained matrix soils are more frost susceptible than coarsegrained deposits. These changes resulted in 29 surficial material units represented in our models (Fig. S1 in the Supplement). Each surficial material unit was assessed in terms of general grain size characteristics and deposit type, which are pertinent to ground ice formation and permafrost preservation. For example, fine-grained offshore lacustrine and marine units are highly frost susceptible, favouring the formation of segregated ice (e.g., Chamberlain, 1981) and a protective surface organic layer (Tarnocai et al., 2011), whereas dominantly coarse-grained deposits are less frost susceptible and less likely to support permafrost in warmer climates (Jorgenson et al., 2008). Similar to the Brown et al. (1997) map, we consider overburden thickness in our assessment, based on surficial material units, i.e., sediment veneers vs. blankets (Fig. S1).

A time series of deglaciation and paleovegetation maps (Dyke et al., 2004) was used to iteratively modify ground ice abundance through 14 time steps from 14 to 1 uncalibrated ka (17.2 to $0.9 \mathrm{ka}$; Fig. S2). Four biome classes were considered to generalize climate and permafrost conditions during this period: (i) herb tundra (very cold continuous permafrost), (ii) shrub and alpine tundra (cold continuous permafrost), 
(iii) forest tundra (warm discontinuous permafrost), and (iv) boreal forest and all other biomes (sporadic or isolated permafrost and seasonally frozen ground) (e.g., Burn and Kokelj, 2009; Heginbottom et al., 1995; Smith et al., 2010). The biome distributions control the rate of wedge ice accumulation and the melt of relict and segregated ice in the models due to transitions between tundra and forest during the Holocene (Fig. 1). The time series of ice sheet, glacial lake, and marine limit configurations on the paleovegetation maps are originally from deglaciation maps for North America (Dyke et al., 2003) and are used to define the timing of subaerial exposure in the wedge ice model (Fig. 1). Maximum glacial lake and marine limits from the Glacial map of Canada (Prest et al., 1968) were used to represent Holocene thaw of relict ice due to submergence (Fig. 1). Justification for the inclusion of these processes and responses in the models is provided in Sect. 3.1.-3.3. with reference to the pertinent literature. The contemporary permafrost distribution was used to modify ice abundance based on the likelihood of permafrost in different surficial material units (Heginbottom et al., 1995).

The original vector datasets were converted to raster with $1 \mathrm{~km}^{2}$ pixels. The spatial resolution was used to produce smooth cartographic boundaries, though the typical map unit of the underlying surficial geology dataset is much coarser in resolution, and the paleovegetation and deglacial limits are generalized (Fig. S2). Ground ice abundance in the top $5 \mathrm{~m}$ of permafrost is reported for each ice type qualitatively as "high", "medium", "low", "negligible" and "none". The none class represents no excess ground ice in non-permafrost areas, and a general absence in permafrost regions; however areas mapped as bedrock at the scale of the surficial geology dataset may include some sediment cover that hosts ground ice. The model uses ranked numeric values to account for ground ice abundance in the computational steps, but these do not represent absolute quantities or percentages.

\subsection{Relict ice model}

The relict ice model represents preserved buried glacial ice. An initial numeric abundance value is assigned to each surficial material unit in the GIS. Values are highest for thick, fine-grained hummocky till and moraine deposits, as these commonly include buried glacier ice (Evans, 2003; Kokelj et al., 2017) and are also associated with past ice margins where conditions may have been conducive to intrasedimental ice development (Mackay and Dallimore, 1992; Rampton, 1988a; Table S1 in the Supplement). Glaciofluvial sediments are assigned a medium value, as glacier ice may be buried by outwash deposits (Coulombe et al., 2019; Evans, 2003; Wolfe et al., 2017). Values are modified through the 14 time steps based on changes in biome distributions and marine and glacial lake inundation, representing melt due to large-scale Holocene environmental changes (Table S2). The partial melt of relict ice is assumed in the modern continuous permafrost zone when tundra transitions to forest tundra and/or boreal forest during the Holocene, as a warmer climate and wildfires near the tree line cause increases in active-layer thickness that may partially thaw near-surface permafrost (Kokelj et al., 2017; Mackay, 1995; Murton, 2001). Marine and glacial lake inundation reduce relict ice abundance to zero in the model (Table S2). Although marine settings may preserve ground ice in sub-zero saline waters, most submerged sediments would be subject to a range of water depths and temperatures that are more likely to melt relict ice than preserve it. Dyke and Savelle (2000) have indicated that moraine volumes are considerably reduced where they extend below marine or glacial lake inundation limits. This reduction indicates that inundation either prevented the formation of relict ice or caused it to melt rapidly (Evans, 2003). Finally, the modern-day permafrost distribution is applied and relict ice remains preserved in the continuous permafrost zone. Relict ice is considered to melt completely from the modern discontinuous permafrost zone in the model, where ground temperatures are relatively high and frequent forest fires cause significant increases in active-layer thickness (Burn, 1998; Viereck, 1983). The latitudinal decline of slump-affected terrain in the western Arctic over the transition to discontinuous permafrost likely reflects this thaw of relict near-surface ground ice (Kokelj et al., 2017), and there have been no reported observations of relict ice at exposures in the discontinuous permafrost zone in Canada (Table S3). The resulting values represent the relative abundance of relict ice preserved in permafrost.

\subsection{Segregated ice model}

An initial segregated ice value is assigned to each surficial material (Table S4), representing the frost susceptibility based on general soil texture (Chamberlain, 1981). Frost susceptibility was assessed for each surficial material unit using legend descriptions from the Surficial geology of Canada map, descriptions in other source material (e.g., Fulton, 1989), and expert knowledge of the surficial geology of northern Canada (Table 1). Smith and Burgess (2004) similarly assigned frost susceptibility values to surficial material units in an assessment of the physical response of permafrost terrain to climate warming. The segregated ice values may decline following biome transitions from tundra to boreal forest, reflecting the partial melt of near-surface ground ice during Holocene warm periods (Burn, 1988; Table S5). The values also decrease in discontinuous permafrost zones (Table S6), representing the decrease in areal extent of permafrost and preferential thaw in coarse-grained units. It should be noted that these reductions reflect an overall decrease in ice abundance in the mapping units, though segregated ice content may remain high locally in remnant palsas and lithalsas. 


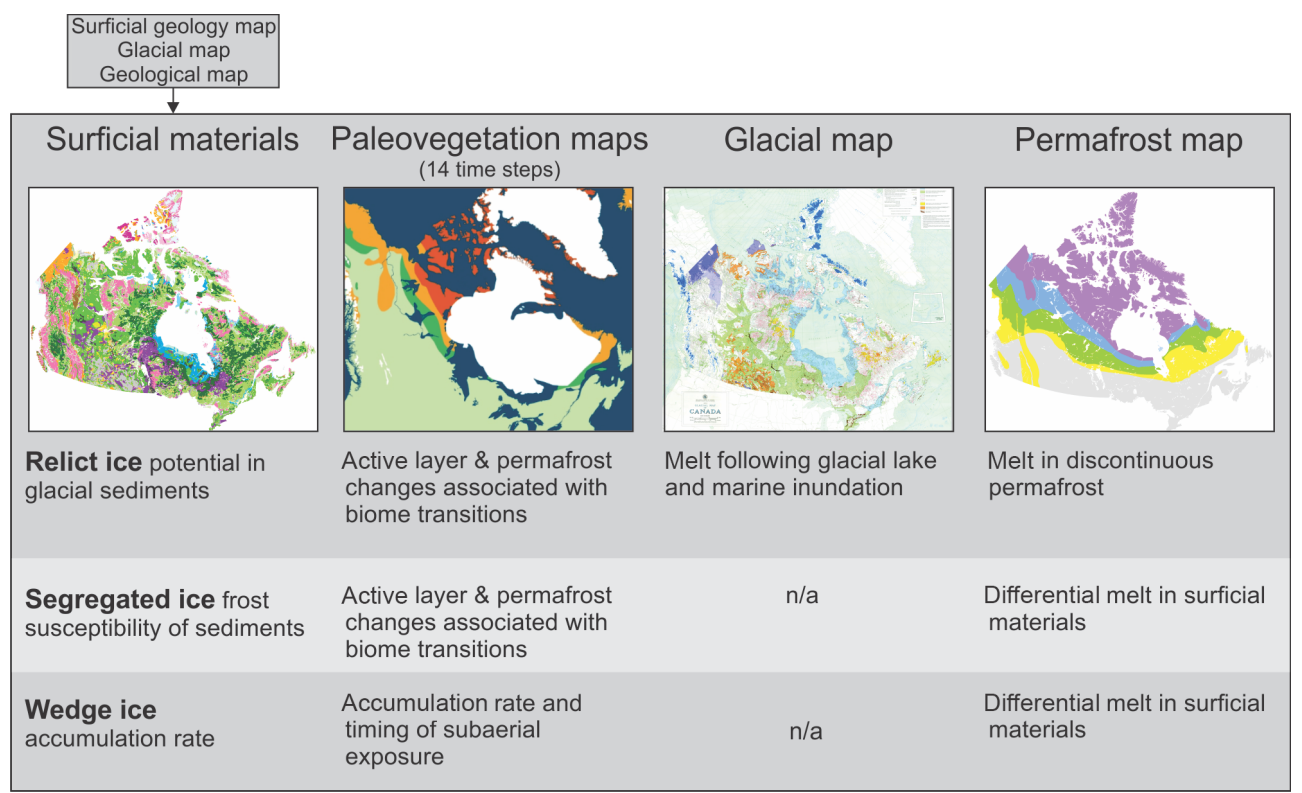

Figure 1. General model framework indicating datasets used and processes represented for the three ground ice types. See text for descriptions of each dataset.

Table 1. Examples of surficial material units, soil texture, and resulting assessment of frost susceptibility.

\begin{tabular}{|c|c|c|}
\hline Surficial material & Soil texture & $\begin{array}{l}\text { Frost } \\
\text { susceptibility }\end{array}$ \\
\hline Mo: marine offshore & Dominantly silt and clay (Geological Survey of Canada, 2014) & High \\
\hline A: alluvial undifferentiated & Silt, sand, clay, and gravel (Geological Survey of Canada, 2014) & Medium \\
\hline $\begin{array}{l}\text { CC: colluvial undifferentiated } \\
\text { (coarse) }\end{array}$ & $\begin{array}{l}\text { Blocks, rubble with sand, and silt with minor clay } \\
\text { (Geological Survey of Canada, 2014) }\end{array}$ & Low \\
\hline Wv: weathered regolith veneer & Rubble to blocky felsenmeer (Geological Survey of Canada, 2014) & Negligible \\
\hline
\end{tabular}

\subsection{Wedge ice model}

Ice-wedge cracking typically occurs when ground temperatures fall below -10 to $-15^{\circ} \mathrm{C}$, usually in midwinter to late winter (Allard and Kasper, 1998; Fortier and Allard, 2005; Kokelj et al., 2007a; O'Neill and Christiansen, 2018). Snow cover and winter air temperatures critically control these ground thermal conditions (Lachenbruch, 1962; Mackay, 1974, 1992). Both winter air temperatures and snow depths generally decrease northward from boreal forest to tundra (Atlas of Canada, 2010; Palmer et al., 2012). In tundra, snow cover properties are dominantly controlled by vegetation characteristics and site-scale topography (Essery and Pomeroy, 2004). Shrubs trap windblown snow, protecting it from densification and sublimation, which promotes thicker snow cover and warmer ground temperatures than in barren tundra (Liston et al., 2002; Sturm et al., 2001). The northward decrease in air temperature and snow depth results in an associated decline in ground temperatures (Burn and Kokelj, 2009; Smith et al., 2010).
There are few long-term records of ice-wedge cracking in Canada, but these generally indicate decreasing cracking frequency moving from tundra to forest environments in response to warmer ground temperatures (Kokelj et al., 2014). Observations by J. Ross Mackay provide a wealth of information from the western Canadian Arctic (Burn, 2015), and results from monitoring on Bylot Island, Nunavut, are also instructive (Fortier and Allard, 2005). In herb tundra on Bylot Island, cracking monitored at two ice wedges occurred in four $(67 \%)$ and five (83\%) out of six winters, with both wedges cracking in three winters (Fortier and Allard, 2005). In low shrub tundra at Garry Island, Northwest Territories, cracking frequency at one site over 12 years was $8 \%-42 \%$ and at another $22 \%-75 \%$ over 20 years. Ice-wedge cracking frequency in 1968-1973 at 10 sites decreased linearly with snow depth (Mackay, 1974, Fig. 19). At the Illisarvik drained lake basin on Richards Island, Northwest Territories, ice-wedge development was rapid on the initially barren drained lake bottom (Mackay, 1986). Cracking frequencies decreased as vegetation established and snow cover increased, and all cracking ceased when snow depths reached 
about $0.6 \mathrm{~m}$ (Mackay, 1986; Mackay and Burn, 2002b). Near the tree line at Inuvik, Northwest Territories, no cracking was recorded at 12 locations in forest in 1980-1988 (Mackay, 1992). The growth of spruce trees in many of the troughs attested to infrequent recent cracking. Similarly, ice-wedge cracking is inactive in white spruce forests in the eastern Mackenzie Delta (Kokelj et al., 2007a). Infrequent cracking during cold years led to the formation of thin ice veins in the boreal forest in central Yukon Territory since the 1950s (Burn, 1990). In Alaska, ice wedges are typically weakly active or inactive in forested areas of the discontinuous permafrost zone (Jorgenson et al., 2008). However, it is unlikely that significant wedge ice accumulates in the northern boreal forest since the recurrence interval of fires is commonly < 150 years (Johnson, 1979; Larsen, 1997; Payette et al., 1989; Viereck, 1983). These environmental conditions cause the size of ice wedges and the density of polygonal terrain to decrease southward across the tundra-forest transition (Kokelj et al., 2014).

Wedge ice abundance is modelled over the 14 time steps. Ice accumulates over time as terrain becomes exposed following deglaciation or lake/marine recession. Based on available empirical data on ice-wedge cracking and broad patterns of vegetation, snow cover, and ground temperature, we assume the rate of wedge ice growth is greatest in herb tundra, moderate in shrub and alpine tundra, and low in forest tundra (Table S7). Wedge ice accumulation is considered most rapid within herb tundra in thick, fine-grained sediments, where cold winter air temperatures and thin snow cover are conducive to frequent and deep thermal contraction cracking (Lachenbruch, 1962). Wedge ice remains preserved but ceases to accumulate in areas that transition from tundra to boreal forest biomes, as ground thermal conditions in forest are typically not favourable for ice-wedge cracking (Burn, 1990; Kokelj et al., 2007a, 2014; Table S7). Finally, the current permafrost distribution from Heginbottom et al. (1995) is used to model the differential melt of ice wedges in discontinuous permafrost depending on the surficial material (Table S8). For example, wedge ice is assumed to melt from coarse-grained glaciofluvial deposits in the discontinuous, sporadic, and isolated permafrost zones, as these materials are subject to deep thaw following forest fires and are unlikely to contain permafrost in warmer climates. The resulting accumulated numeric values are reclassified as high, medium, low, and negligible abundance using the quantile method (Table S9).

\section{Results}

Modelled relict ice abundance mainly reflects the distribution of thick glacigenic sediments in regions that have remained in herb and shrub tundra environments since deglaciation and occur in the modern continuous permafrost zone (Fig. 2). High abundance occurs in four main areas: (1) western Arctic

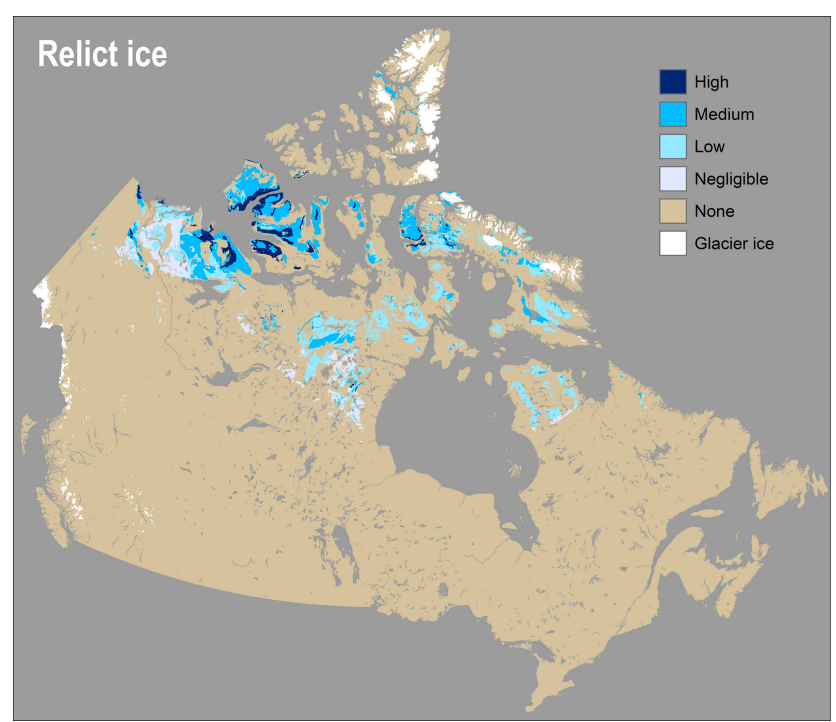

Figure 2. Modelled relict ice abundance.

islands, including Banks and Victoria islands; (2) the western Arctic mainland; (3) the central Canadian Shield; and (4) northwest Baffin Island. Areas of high relict ice abundance constitute about $2 \%$ of the continuous permafrost zone in Canada and areas of medium abundance about $9 \%$.

Modelled segregated ice is widely distributed owing to the ubiquity of fine-grained surficial materials in northern Canada. High abundance occurs in areas covered by marine or lacustrine sediments that are in tundra of the continuous permafrost zone (Fig. 3). Areas of high abundance occupy about $3 \%$ of the continuous and $4 \%$ of the discontinuous permafrost zones. Areas of medium segregated ice abundance are widespread, occupying about $25 \%$ of the continuous and $17 \%$ of the discontinuous permafrost zones. These areas largely reflect the distribution of till derived from sedimentary bedrock, particularly in northwestern Canada, which may include a significant fine-grained fraction. Paleovegetation distribution also influences modelled segregated ice, particularly in the Mackenzie Valley of the western Arctic where Holocene tree line advance causes a modelled reduction in ice abundance.

Modelled wedge ice abundance largely reflects exposure time of unconsolidated sediments to cold climatic conditions. The pattern of deglaciation and Holocene environmental history thus strongly control the modelled wedge ice distribution. Abundance is high where herb and shrub tundra have persisted for long periods (ca. $13 \mathrm{ka}$ ), including the western Arctic islands and some areas of the western Arctic mainland and coast (Fig. 4). As with segregated ice, a corridor of negligible wedge ice abundance in the western Arctic is associated with Holocene tree line advance. Areas of high and medium wedge ice abundance comprise about $2 \%$ and $10 \%$ of the modern continuous permafrost zone, respectively. Wedge ice abundance is generally low and negligible in the discontin- 


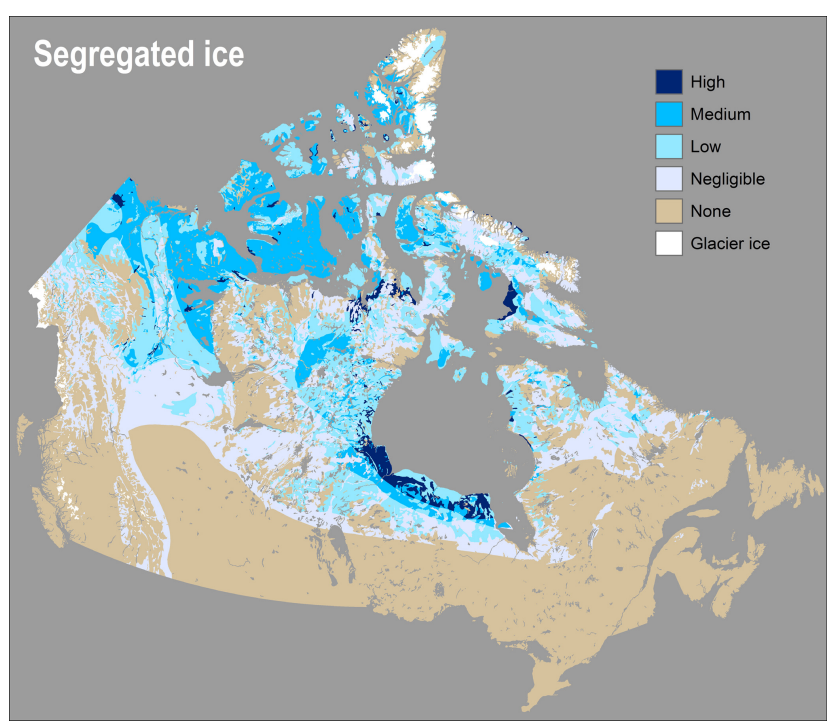

Figure 3. Modelled segregated ice abundance.

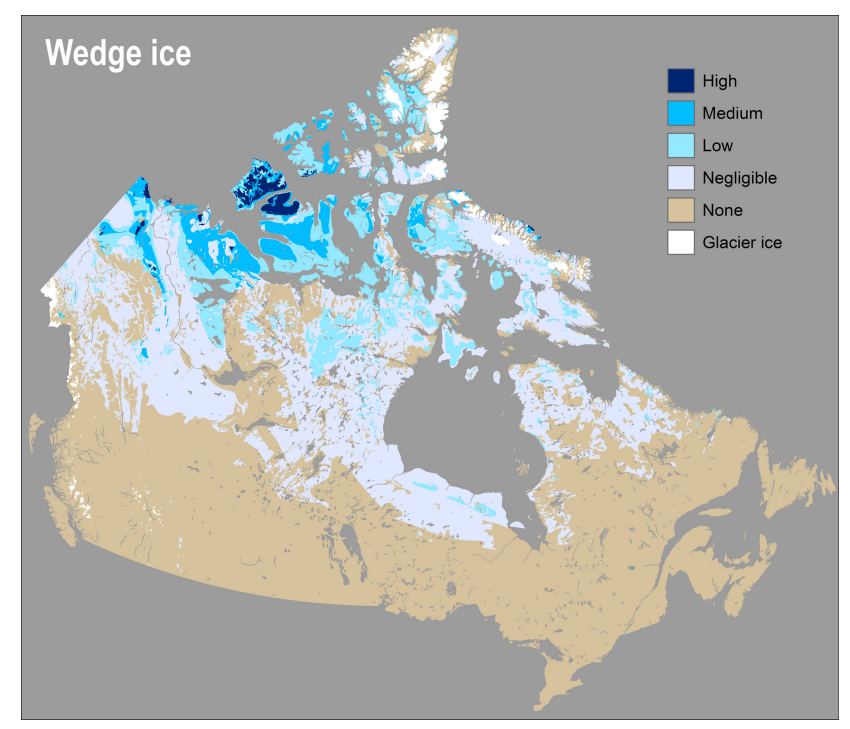

Figure 4. Modelled wedge ice abundance.

uous and isolated permafrost zones, reflecting the limited time that tundra conditions persisted following deglaciation in more southerly regions.

\subsection{Model evaluation}

The model validation process may include a number of techniques, but validation ultimately depends on whether the model behaviour seems reasonable to knowledgeable people given the stated model objectives and performance criteria (Riseborough et al., 2008; Rykiel, 1996). Our modelling objectives were to produce an updated depiction of ground ice in Canada, encourage questions that guide new ground ice investigations, and identify requirements to advance fu- ture modelling efforts. Systematic observations of different ground ice forms are still lacking from many areas, making quantitative validation techniques in most areas impossible. Therefore, we present comparisons among the model outputs, available field observations, and the ground ice mapping of Heginbottom et al. (1995). As more data become available or are compiled, continued scrutiny of the methodology, parameterization, and outputs will permit improvements through an iterative modelling approach (e.g., Overton, 1977), contributing to an improved understanding and depiction of ground ice in permafrost in North America.

\subsubsection{Relict ice}

Areas with high modelled relict ice abundance correspond well with the distribution of large thaw slumps, which typically develop in areas underlain by thick layers of relict ice (Kokelj et al., 2017), helping validate the model in northwest Canada (Fig. 5). The model reproduces relict ice observed directly or interpreted from thaw slump mapping on Banks Island, Victoria Island, the western Arctic mainland, the central Canadian Shield, and Ellesmere Island (Fig. 5b; see Fig. S3 for specific locations mentioned throughout the text). Areas of high ice abundance are associated with hummocky till and moraine deposits that have remained in tundra and continuous permafrost during the Holocene. Field observations of relict ice from the discontinuous permafrost zone are lacking, as is indirect evidence in the form of large thaw slumps (Fig. 5b). The model also depicts relict ice in medium and lower abundance in other glacigenic terrain of the continuous permafrost zone that was not inundated during the Holocene. It is difficult to evaluate results in many of these areas due to the lack of field evidence. Nonetheless, it seems reasonable that relict ice may remain preserved in other till and glaciofluvial deposits.

\subsubsection{Segregated ice}

Areas with high modelled segregated ice abundance occur in raised marine and in glacial lake sediments and correspond to observations of widespread shallow thaw lakes, lithalsas, palsas, and peat plateaus (Fig. 6). High segregated ice abundance is modelled in Old Crow Flats in northern Yukon where there are about 2700 shallow thermokarst lakes with an average depth of $<2 \mathrm{~m}$ (Turner et al., 2014). In epigenetic permafrost, segregated and wedge ice is concentrated in the upper sediments, which explains the shallow thaw lake depths (Matthews et al., 1990; Roy-Leveillée and Burn, 2015, 2017). High segregated ice abundance is modelled in the Hudson Bay Lowlands and is evident in the form of widespread palsas and peat plateaus in the uplifted fine-grained marine sediments (Kuhry, 2008; Payette, 2004). High abundance is also modelled around Umiujaq on eastern Hudson Bay, where both palsas and lithalsas are common (Allard and Seguin, 1987; Calmels et al., 2008b). Southwest- 

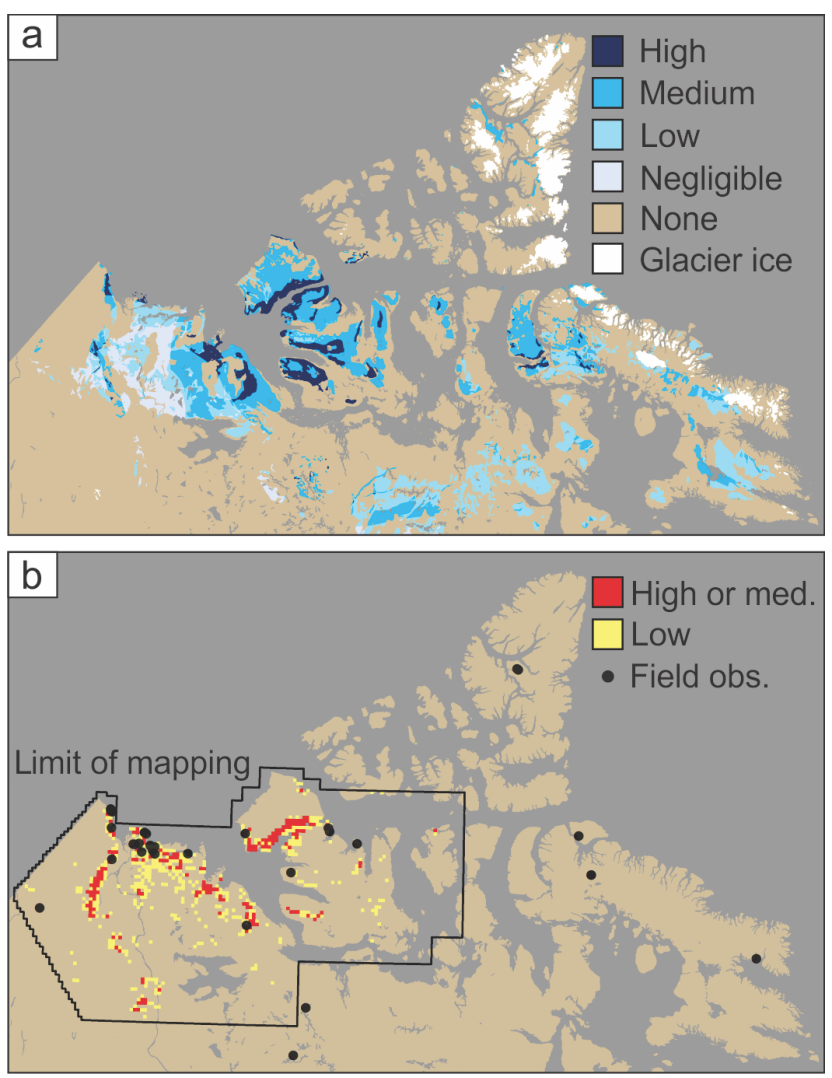

Figure 5. (a) Modelled abundance of relict ice and (b) abundance of large ( $>1$ ha) thaw slumps in northwest Canada (Kokelj et al., 2017; Segal et al., 2016), and field observations of relict ice from the literature (Table S3).

ern Baffin Island also includes high segregated ice abundance where shallow $(<2 \mathrm{~m})$ thaw lakes and drained lake basins are widespread on the Great Plain of the Koukdjuak (Martini and Morrison, 2014).

High segregated ice abundance modelled on small parts of the Fosheim Peninsula on Ellesmere Island correspond to areas covered by fine-grained, ice-rich deposits (Pollard, 1991). Massive intrasedimental ice may underlie these deposits and is considered to have formed by segregation during permafrost aggradation into sands and silt overlying unfrozen coarse strata with highly pressurized groundwater (Pollard, 2000; Robinson and Pollard, 1998). These specific formation conditions following marine emergence are not considered in either the relict or segregated ice model, but the general near-surface ice conditions are nonetheless represented by the high modelled segregated ice abundance. Medium segregated ice abundance is modelled over much of the western Arctic mainland and Banks and Victoria islands in till derived from sedimentary bedrock. These areas also include abundant shallow thaw lakes (Burn, 2002; Dallimore et al., 2000) and thaw slumps (e.g., Lantz and Kokelj, 2008). Further south in the discontinuous permafrost zone,

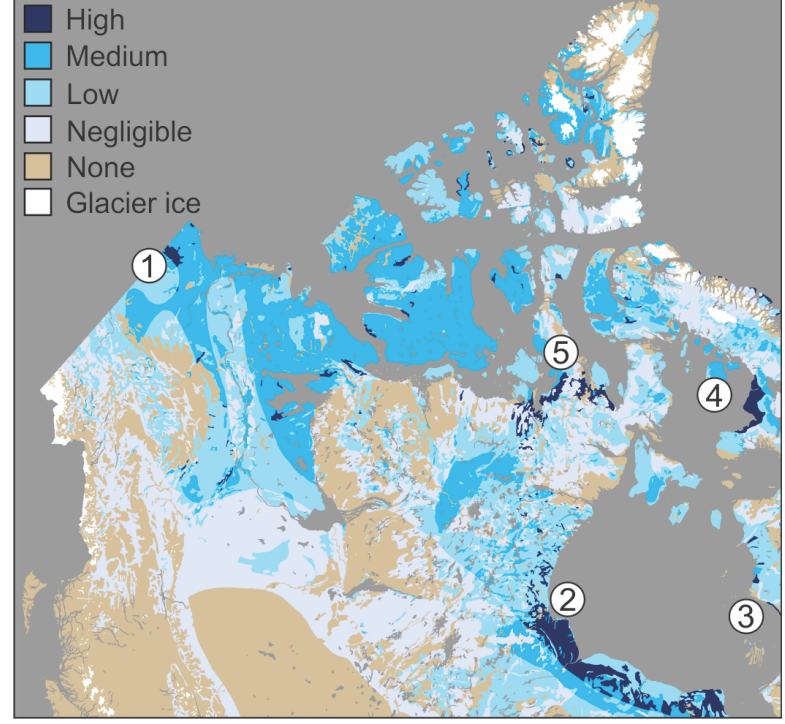

Figure 6. Modelled abundance of segregated ice. Old Crow Basin (1) is characterized by widespread excess ice in fine-grained lacustrine sediments and an abundance of shallow thermokarst lakes. Within the Hudson Bay Lowlands (2), areas with high segregated ice abundance include extensive raised peat plateaus. Lithalsas are widespread in raised marine sediments at Umiujaq (3). The Great Plain of the Koukdjuak (4) and southern Boothia Peninsula (5) also include fine-grained uplifted marine sediments, and shallow thaw lakes are abundant in both regions.

small thaw slumps and active layer detachment slides occur in the Mackenzie Valley where segregated ice abundance is largely modelled as low or medium (e.g., Couture and Riopel, 2008).

\subsubsection{Wedge ice}

The modelled distribution of wedge ice generally corresponds to field and remote-sensing observations of ice wedges and polygonal terrain. The size of ice wedges and the density of polygonal terrain decreases southward across the tundra-forest transition in the western Arctic (Kokelj et al., 2014), and the wedge ice model reproduces this general pattern as an increase from negligible to high wedge ice abundance (Fig. 7). Areas of modelled negligible wedge ice abundance in forest-tundra generally correspond to small ice wedges observed only in organic soils. Low wedge ice abundance corresponds to small to moderately sized ice wedges observed in both mineral and organic soils in shrub tundra (Kokelj et al., 2014). Areas of medium ice-wedge abundance correspond to medium to large ice wedges observed further north in dwarf-shrub tundra (Fig. 7). Pollard and French (1980) estimated that wedge ice on Richards Island constitutes about $12 \%$ of the upper $4.5 \mathrm{~m}$ of permafrost, where the modelled abundance is medium to high (Fig. 7a). 

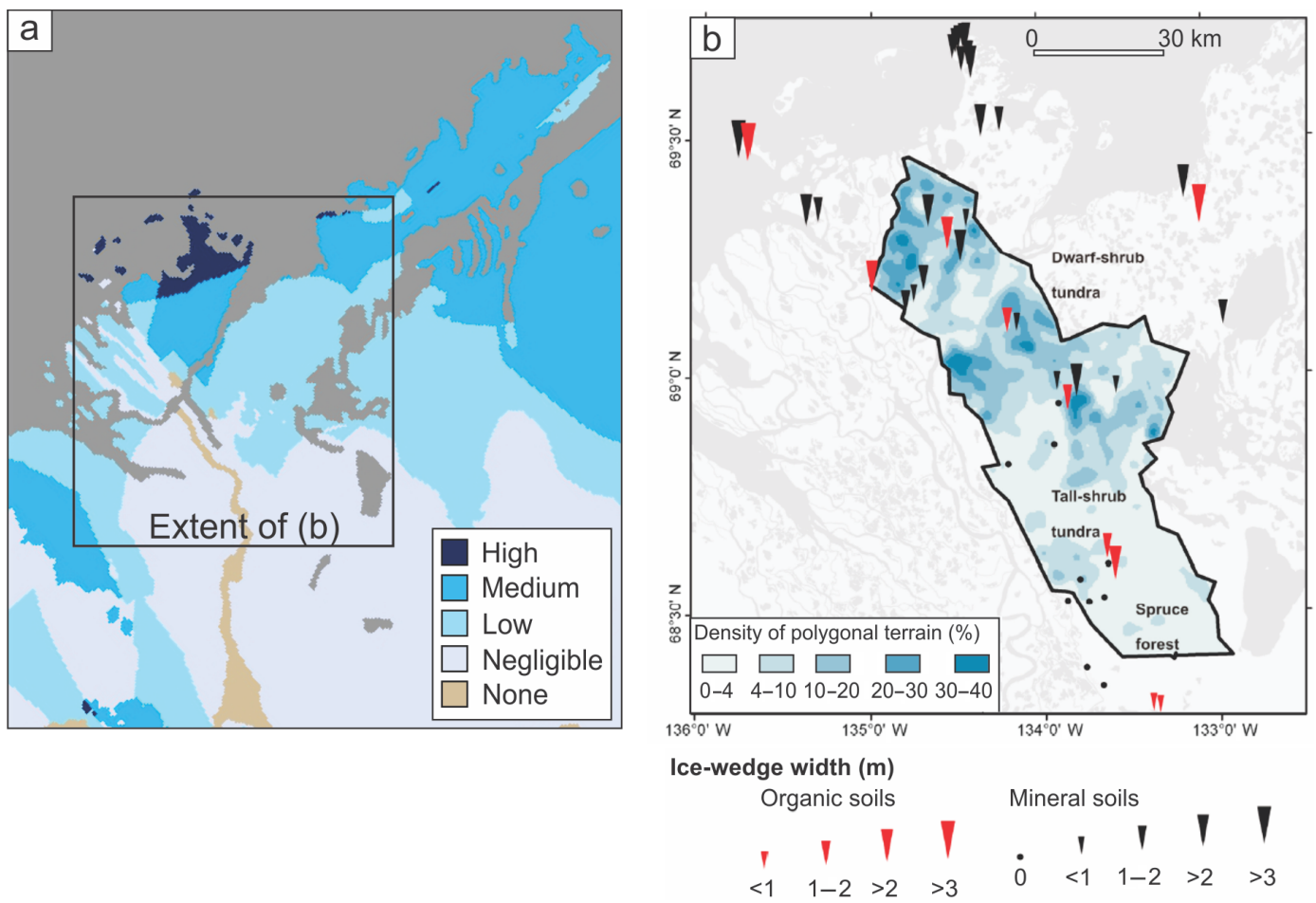

Figure 7. Comparison of (a) modelled wedge ice abundance to (b) wedge widths and the density of polygonal terrain in the western Canadian Arctic (modified from Kokelj et al., 2014, Fig. 6).

High wedge ice abundance is modelled over large areas of Banks and Victoria islands (Fig. 4). Evidence of abundant large ice wedges is available from imagery and from field investigations on Banks Island. Ice wedges may exceed $3 \mathrm{~m}$ in width and $10 \mathrm{~m}$ in depth and comprise up to $15 \%$ of the volume of upper ground (French, 1974). The formation of large ice wedges in this environment occurs due to the persistence of an Arctic climate for millennia. In addition, wedge growth may be facilitated where it occurs in relict ice, which has a high thermal contraction coefficient, promoting wide and deep thermal contraction cracking (Lachenbruch, 1962). A recent image analysis of Banks Island highlighted the widespread degradation of large ice wedges and the resulting broadscale increase in ponding in flatter terrain (Fraser et al., 2018).

Recent estimates on Fosheim Peninsula indicate that icewedge polygons cover about $50 \%$ of the terrain and that wedge ice occupies between $1.4 \%$ and $5.9 \%$ volume of the upper $5.9 \mathrm{~m}$ of permafrost (Bernard-Grand'Maison and Pollard, 2018). In this region, wedge ice abundance is modelled mostly as low, with some small areas of medium abundance (Fig. 4). The modelled wedge ice abundance and field- or imagery-derived wedge volume estimates are thus generally consistent for Banks Island, Richards Island, and Fosheim Peninsula.

\subsection{Comparison with previous mapping}

The broad patterns of modelled relict, segregated, and wedge ice abundance are similar to those mapped by Heginbottom et al. (1995) on the Permafrost Map of Canada, but the modelled results are more spatially explicit and portray ground ice conditions more accurately in many regions. The modelled ground ice abundance was compared to the PMC by standardizing the legends and producing a difference map using a raster combination (Table 2; Fig. 8). The ice class on the PMC that includes "segregated ice, intrusive ice, reticulate ice veins, ice crystals and ice coatings on soil particles" was considered analogous to the modelled segregated ice in this paper since reticulate veins and ice coatings on soil particles also form by segregation, and intrusive ice forms only under localized conditions. Massive ice on the PMC is considered analogous to modelled relict ice and is referred to as such in the comparison. The comparison for each ice type is not exhaustive, but rather focuses on regions with significantly different assessed ice abundance: i.e., (1) where our models indicate high ground ice abundance and the PMC indicates low or none; (2) where the PMC indicates high ground ice abundance and our models indicate low or none (see Table 2; Fig. 8). 
Table 2. Raster reclassification used to produce the ground ice abundance difference map between the Permafrost map of Canada (PMC) (Heginbottom et al., 1995) and the models (M).

\begin{tabular}{llll}
\hline Reclassified value & \multicolumn{3}{c}{ Original map legend } \\
\cline { 2 - 4 } & $\begin{array}{l}\text { PMC massive, } \\
\text { wedge }\end{array}$ & PMC segregated & $\begin{array}{l}\text { M } \\
\text { (all ice types) }\end{array}$ \\
\hline High (2) & Abundant & High, med-high, med & High, medium \\
Low (1) & Sparse & Low-med, Low & Low, negligible \\
None (0) & Absent & Nil-low, None & None \\
\hline
\end{tabular}

\subsubsection{Relict ice}

Both representations generally depict abundant ice on the western Arctic mainland and Banks and Victoria islands, but the model output is more spatially defined and more accurately reflects current knowledge of the distribution of relict ice (Figs. 2, 8a). For example, no relict ice is modelled on southeastern Victoria Island, where marine inundation is considered to have melted relict ice (Figs. 2, 8d). This interpretation is supported by the lack of large thaw slumps mapped in the region (Fig. 5b; Kokelj et al., 2017). The PMC indicates abundant relict ice over most of the Canadian Arctic Archipelago islands northeast of Banks and Victoria islands (Fig. 8a, d). In contrast, the model indicates that relict ice is absent on most of these islands, as the surficial materials are regolith or colluvium and are thus unlikely to include large preserved ice bodies. In addition, many of the islands were partially or fully inundated following deglaciation. On the Great Plain of the Koukdjuak, western Baffin Island, the PMC indicates abundant relict ice. However, the region was also marine inundated, and the shallow depths and consistent shape of the lake basins there indicate thaw of uniformly distributed segregated ice restricted to upper sediments rather than of thicker relict ice bodies (Martini and Morrison, 2014). In the Peel Plateau region, areas of high and medium modelled relict ice abundance occur where widespread exposures have been observed directly and mapped using remotely sensed imagery (Kokelj et al., 2015; Lacelle et al., 2015). In contrast, the PMC indicates that relict ice is absent or sparse in this region (Fig. 8a, d). The model indicates an absence of relict ice in Old Crow Flats, whereas the PMC indicates that it is abundant (Fig. 8d). The region includes abundant ice wedges, a thin layer of near-surface segregated ice, and resulting shallow thermokarst lakes (Labrecque et al., 2009; Roy-Leveillée and Burn, 2017), but evidence of relict ice is lacking. The past submergence of the area by glacial Lake Old Crow and associated deposition of thick glaciolacustrine sediments precludes the preservation of relict ice, so the modelled output is more appropriate. In the northern Mackenzie Valley region, the relict ice abundance is higher on the PMC than the model output (Fig. 8d). Low, negligible, and no relict ice is indicated by the model due to the presence of different till units (hummocky, blanket, veneer) and reductions in modelled abundance due to Holocene tree line advance in the region. The large physiographic unit with abundant ice on the PMC extends south to areas with little evidence in the form of large thaw slumps (Fig. 5b). In these examples the modelled distribution of relict ground ice is in better agreement with available empirical data and more spatially discrete than the portrayal on the PMC. Further empirical investigations are required to assess the model outputs in some areas, such as on Brodeur Peninsula on northwest Baffin Island and on the central Canadian Shield, where the modelled abundance is higher than on the PMC (Fig. 8d).

\subsubsection{Segregated ice}

The distribution of segregated ice is also broadly similar in the PMC and model output, with relatively high abundance portrayed over much of the western Arctic mainland and islands (Figs. 3, 8b). However, some key differences are evident (Fig. 8e). For example, ice content is considered lowmedium in the Hudson Bay Lowlands on the PMC, whereas the model output indicates high abundance in the extensive fine-grained marine sediments (Fig. 8e). Smith and Burgess (2004) similarly mapped this region as having high thaw sensitivity due to high ground ice content. Given the abundance of peat plateaus and palsas in this region and the evident landscape change that has occurred due to recent ground ice melt (Payette, 2004), the high modelled segregated ice abundance is more appropriate. The PMC indicates a higher abundance of segregated ice than the model in some areas on eastern and high Arctic islands (Fig. 8e). However, many of these areas are covered by weathered regolith or bedrock, which are not highly frost susceptible and thus likely contain little excess ice. The modelled abundance is higher than the PMC in some areas mapped as fine-grained colluvium, notably on parts of Axel Heiberg and Melville islands. High segregated ice abundance is indicated on the northeast Tuktoyaktuk coastlands on the PMC, whereas the model indicates a general absence (Fig. 8e). The surficial materials in this area are largely eolian sand and sandy outwash that contain little segregated ice (Rampton, 1988b). Some small areas with frost-susceptible lacustrine deposits are also present (Rampton, 1988b) but not mapped at the scale of the surficial geology dataset used 

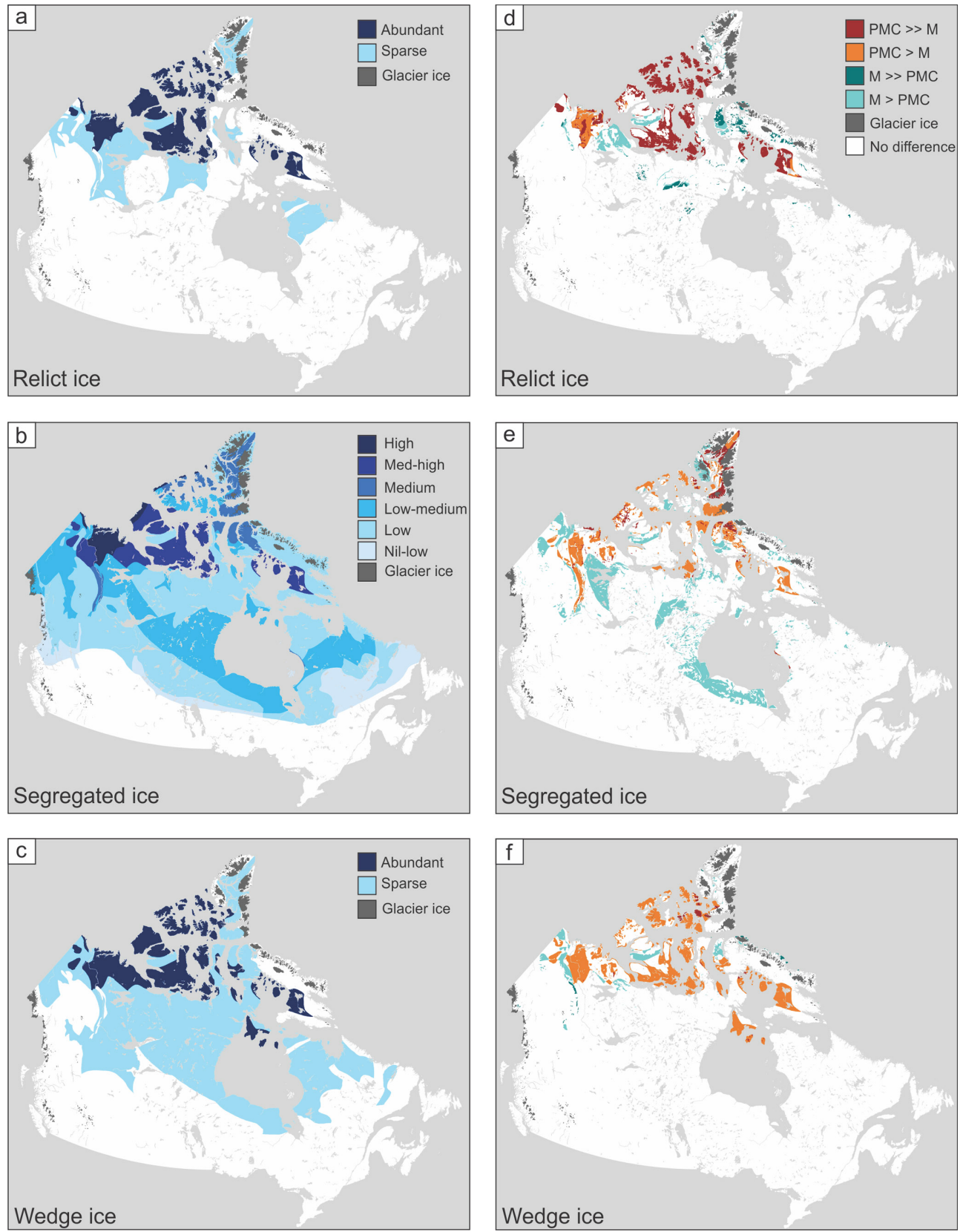

Figure 8. The Permafrost map of Canada (PMC) depictions of (a) relict ("massive") ice, (b) segregated ice, and (c) wedge ice (modified from Heginbottom et al., 1995). Panels (d-f) present comparisons between the PMC and the models (M). PMC $\gg$ M indicates, for example, that the reclassified relative ground ice abundance in the PMC is "high" and the modelled abundance is "none". M $>$ PMC indicates the reclassified ground ice abundance is "high" in the model output and "low" in the PMC. See Table 2 and text.

in the model. The PMC indicates high segregated ice abundance in the Mackenzie Valley area south of the tree line, where the modelled abundance is reduced to represent periodic thaw and loss of ice from the upper permafrost (Burn, 1988; Shur et al., 2005). This modelled pattern requires further investigation. The model indicates high or medium segregated ice abundance in many areas of the central Canadian Shield that include frost-susceptible sediments, whereas the
PMC indicates low-medium or low ice content in the encompassing physiographic regions (Fig. 8e). The difference map in Fig. 8e highlights how the surficial geology base map leads to a more detailed depiction of segregated ground ice that accounts for the heterogeneity in frost susceptibility of surficial materials. The model depiction is an improvement in several regions, but further evaluation using field datasets is required in some areas to better assess the outputs. 


\subsubsection{Wedge ice}

Broad patterns of wedge ice abundance are similar in the model output and the PMC, with areas of high abundance concentrated in the western Arctic (Figs. 4, 8c). However, the PMC indicates more wedge ice on many of the islands of the central and northern Canadian Arctic Archipelago (Fig. 8f). The modelled abundance on these islands is generally low or negligible because the substrate is dominantly coarse-grained and thin regolith, which does not favour ice-wedge development. Small areas of medium and high abundance are modelled near some coasts in fine-grained till and marine deposits and in fine-grained colluvium in areas with sedimentary bedrock. The lower modelled abundance on most of the islands is a more reasonable depiction, particularly considering the lack of polygonal terrain visible in imagery compared to Banks Island, where large ice wedges are widely distributed and the modelled abundance is high (Fraser et al., 2018). Abundant ice wedges are indicated in the PMC on southwest Baffin Island on the Great Plain of the Koukdjuak (Fig. 8c). In contrast, our model results indicate only negligible to low wedge ice abundance in the area (Fig. 4), partly because the plain has only been terrestrially exposed for ca. $4 \mathrm{kyr}$. The modelled abundance better represents field conditions, as only small incipient ice wedges occur on the plain (Martini and Morrison, 2014). In the northern Mackenzie Valley and Mackenzie Delta regions, modelled wedge ice abundance is lower than indicated on the PMC due to the modelled decrease in wedge ice across the tundra-forest transition (Figs. 4, 8f). As indicated in Sect. 4.1.3, this pattern reproduces the observed southward decrease in polygonal terrain density and wedge width on the western Arctic mainland (Kokelj et al., 2014). Modelled wedge ice abundance is high or medium in the Peel Plateau region but sparse or absent on the PMC. In this case, field observations suggest that the PMC better represents wedge ice conditions, as the distribution of polygonal ground on Peel Plateau is limited to small peatlands that occupy a small proportion of the overall landscape (Steve Kokelj, personal communication, 2018). Section 5.1.2. discusses why the model likely over-represents wedge ice in the region.

These comparisons highlight the limitations of representing ground ice conditions in large physiographic units that may include a range of surficial materials and landscape histories. Overall, the model outputs offer an improved representation of known ground ice conditions by accounting for specific surficial materials and considering the effects of broadscale environmental processes. The apparent inaccuracies in the PMC in many areas necessarily impact the output of other broadscale landscape assessments, such as mapping of thermokarst landscapes and permafrost hazard potential, that use the ground ice distribution as input parameters (e.g., Nelson et al., 2001; Olefeldt et al., 2016).

\section{Discussion}

\subsection{Limitations}

The presented models include several limitations and assumptions that originate from (1) input data validity, (2) conceptual validity, and (3) the calibration of input values (Rykiel, 1996). Nonetheless, the resulting ground ice distributions appear reasonable, recreating broad patterns from previous mapping and improving the depiction in many regions.

\subsubsection{Input data validity}

One of the main challenges of representing complex phenomena over large areas is the precision and accuracy of the source information. The surficial material dataset used in the models, though more spatially detailed than physiographic units used in previous mapping (Brown et al., 1997; Heginbottom et al., 1995) lacks precision and accuracy in some areas. The mapping by Fulton (1995) synthesized maps that were typically $1: 50000$ to $1: 250000$ in scale. The map units for the national representation were compiled at $1: 1000000$ in scale and then photographically reduced to $1: 5000000$ in scale (Fulton, 1995). This reduction caused the removal of some small map units and a loss of detail in the surficial geology dataset (Fulton, 1995). In addition, many areas of Canada and particularly the Arctic remained unmapped at the time of compilation. In these areas, Fulton (1995) relied on available literature and assessments by experts to delineate surficial units. These deficiencies caused inaccuracy in the modelled results in some areas. For example, lithalsas are abundant in glaciolacustrine sediments along the northern shore of Great Slave Lake near Yellowknife, Northwest Territories (Wolfe et al., 2014). Segregated ice is modelled as either absent or negligible in much of this area because surficial materials are mapped as bedrock and till veneer. More recent mapping has properly identified the widespread glaciolacustrine sediments that host the many ice-cored features in the region (Stevens et al., 2017; Wolfe et al., 2014). Therefore, the model output could be improved by including updated surficial geology mapping. These data are becoming available in a consistent digital format through new mapping and conversions of existing maps by the Geological Survey of Canada (Deblonde et al., 2018).

The generalized paleogeographic datasets, although fundamental to the model, are inherently limited and subject to scrutiny regarding the timing and spatial extent of the last glaciation, deglacial limits, lake and sea levels, and biome distributions. For example, the paleovegetation dataset of Dyke et al. (2004) has several limitations that affect model results. The biome distributions are based on a relatively large dataset of pollen sites and plant and terrestrial mammal macrofossils across northern North America $(n=4659)$, but these observations are most limited in modern herb, shrub, 
and forest tundra environments. Therefore, the interpretation of biomes and their limits are approximations, particularly in northern regions. Second, the biome distributions reflect climatic factors such as growing season length and the mean temperature of the warmest month, which are not direct analogues of ground thermal conditions. Climatic and vegetation conditions may vary significantly within each of the defined biomes, affecting ground thermal conditions controlling, for example, wedge ice development or the preservation of relict ice.

\subsubsection{Conceptual validity}

Conceptual validity refers to the justifiability of underlying theories and assumptions in the model that represent the system behaviour (Rykiel, 1996). For each model, the causeeffect relations and assumptions are explained in the methods section and Supplement. Necessary assumptions in the expert system do not fully capture the full complexity of conditions known to influence ground ice growth and decay. For example, the relict ice model does not deal with ice melt over time in tundra environments of the continuous permafrost zone resulting from erosional processes. Melt of relict ice may occur irrespective of climatic amelioration due to colluvial, fluvial, or coastal erosion processes, which are controlled by topography, site-scale conditions, and energy and mass transfers that are not represented in the models.

For the wedge ice model, complex relations among air temperature, snow and vegetation conditions, and ground temperature were overly simplified under the broad assumption that ice-wedge cracking frequency increases as air temperature and snow cover decrease from forest to herb tundra (e.g., Kokelj et al., 2014). Regional deviations in air temperature and snow accumulation controlled by synoptic weather patterns and orography were not considered, which may influence wedge ice abundance. For example, the model indicates areas of high wedge ice abundance on Peel Plateau, Northwest Territories, in fine-grained glacigenic sediments that have remained in herb and shrub tundra biomes for much of the Holocene. However, polygonal terrain is sparse in the region. Ice-wedge development may be limited on Peel Plateau because winter ground temperatures in the uplands are relatively high, owing to strong winter air temperature inversions and relatively thick snow cover compared to shrub tundra north of the latitudinal tree line (O'Neill et al., 2015), and these specific regional conditions are not captured in the model. The model indicates negligible wedge ice abundance in some areas of the Hudson Bay Lowlands where dense polygonal networks are visible in satellite imagery. These areas emerged in the mid-Holocene to late Holocene and include forest tundra vegetation, which both lead to low accumulated wedge ice values in the model. In reality, frequent ice-wedge cracking and rapid wedge growth may be facilitated in these plains where the organic cover is thick and there is ample water supply to effectively feed ice vein growth (Allard, 2018).

Finally, the models do not account for the difference in ground ice accumulation due to the mode of permafrost aggradation, i.e., epigenetic or syngenetic. Syngenetic permafrost, which forms contemporaneously with aggrading sediment or organic cover, is commonly more enriched with ground ice than epigenetic permafrost (French and Shur, 2010). In Canada, this has implications for ground ice formation and preservation, particularly where surface organic matter has accumulated during the Holocene. The thermal properties of peat favour aggradation of the permafrost table and the development of thick layers of segregated ice (Burn, 2004; Zoltai and Tarnocai, 1971). In addition, the presence of a surface organic layer may preserve permafrost and underlying inactive ice wedges in environments that no longer support ice-wedge cracking (Shur and Jorgenson, 2007). National-scale datasets of contemporary peatland distribution and thickness are available (Tarnocai et al., 2011), but they do not depict the timing of peat initiation or accumulation over time. Therefore, we do not explicitly consider the important influence of peat accumulation in our models. However, peat accumulation is strongly associated with the hydraulic conductivity of the mineral substrate. Clays and silts have significantly lower hydraulic conductivity than coarser-grained materials, so peat forms preferentially over fine-grained deposits (Tarnocai et al., 2011). Thus, the higher ground ice values assigned to fine-grained lacustrine, marine, and sedimentary bedrock-derived till units indirectly account for the influence of surface organic matter on ice content and the preservation of permafrost. In addition, thick and widespread organic deposits are included in the surficial geology dataset. Nonetheless, the accumulation of peat may be better incorporated in future modelling.

Aggrading fine-grained sediments may also include layers of ice-rich, syngenetic permafrost (Fortier and Allard, 2004; Kanevskiy et al., 2011). Thick Pleistocene loess deposits, sometimes termed "yedoma", occur in the Klondike region and southwest Yukon, preserving syngenetic wedges and segregated ice (Fortier et al., 2018; Fraser and Burn, 1997; Kotler and Burn, 2000). The ice in these deposits formed prior to $17 \mathrm{ka}$ and may extend to $>20 \mathrm{~m}$ in depth and is thus not represented by the modelling. Though the distribution of yedoma in Canada is limited to areas of Yukon, the very icerich nature of the deposits makes them important to consider in a landscape change context. These deposits could be identified in future ground ice mapping products. Other deposit types, such as alluvial fans, are not differentiated at the scale of the surficial geology dataset, so syngenetic ground ice accumulation at depth in these settings is not represented in the models. 


\subsubsection{Input value calibration}

Calibration includes the adjustment of model parameters to improve agreement between model outputs and observations. The development of the models was an iterative process that included multistage assessments of outputs and small adjustments as knowledge of the mapped surficial material units, paleovegetation distributions, and current ground ice conditions was gained. The assignment of values for surficial material units benefitted from conversations with experts on the surficial geology of northern Canada (Dan Kerr, personal communication, 2017, 2018) and examination of map legends from larger-scale surficial geology maps. Volumetric estimates of ground ice, themselves derived by upscaling from relatively few quantitative field data, are available from only a few areas in Canada, including Richards Island, Banks Island, and Fosheim Peninsula (Bernard-Grand'Maison and Pollard, 2018; Couture and Pollard, 1998; French, 1974; Pollard and French, 1980). Therefore, there is insufficient field data to meaningfully calibrate model parameters and quantitatively validate the outputs. It is for this reason that we maintain qualitative descriptors for the ground ice abundance rather than numeric estimates in the map legends.

\subsection{Directions for ground ice modelling and mapping}

Detection and mapping of ground ice over large areas remains challenging. Ground ice volume measurements are required from more areas in Canada to improve validation of small-scale models. Direct observations are only possible at limited exposures and by coring, both of which are logistically demanding. Indirect ground-based geophysical methods such as ground-penetrating radar and electrical resistivity tomography can be used to detect ice bodies but are only applicable in site-scale investigations (Hinkel et al., 2001; Kneisel et al., 2008). Complementary geophysical techniques may allow differentiation and mapping of relict ice, wedge ice, and icy sediments (De Pascale et al., 2008), but accurate volumetric determinations are not yet possible. Because of their distinct polygonal surface expression, volume estimates of ice wedges can be derived using high-resolution imagery (Bernard-Grand'Maison and Pollard, 2018; Ulrich et al., 2014), but their accuracy ultimately depends on field measurements of ice-wedge widths and depths. Air and spaceborne optical, lidar, and D-InSAR techniques allow characterization of thermokarst terrain and processes, offering indirect insights into ground ice conditions (Kääb, 2008; Kokelj and Jorgenson, 2013). Despite these significant recent advances in geophysical and remotesensing techniques in permafrost regions, the lack of assembled data on ground ice and volumetric estimates from different areas in Canada remains a key challenge in assessing the validity of small-scale ground ice models. The compilation of existing ground ice information and new field data from poorly characterized areas will improve calibration and validation of future model outputs.

Combining outputs produced using multiple techniques and perspectives will lead to further improvements to ground ice modelling (e.g., Silver, 2012). For example, pingos identified using remote-sensing techniques could be added as a point data layer. The depiction of deeper ground ice could be improved by accounting for stratigraphic configurations as opposed to surficial cover only and occurrences of icerich syngenetic deposits. Further modelling efforts will benefit from emerging updated surficial geology mapping in a consistent digital format. The paleogeographic approach presented here may also be improved by incorporating revised glacial boundaries and other updated paleoenvironmental information (e.g., Lakeman and England, 2013). Alternate or updated information on permafrost distribution (e.g., Gruber, 2012) could also be utilized, and patterns of ground ice loss could be investigated with projections of future permafrost loss (Chadburn et al., 2017).

The results contribute an improvement in small-scale permafrost mapping for Canada, which has remained unchanged for over 2 decades. The mapping is of practical relevance given recent widespread circumpolar landscape changes that have already been observed in association with ground ice melt (Fraser et al., 2018; Jorgenson et al., 2006, 2015; Kanevskiy et al., 2011; Liljedahl et al., 2016; Rudy et al., 2017). Improved ground ice data layers are valuable for broadscale Earth system modelling and other derived synthetic mapping products. In addition, the modelling approach may also enable depictions of ground ice in past periglacial environments of North America and thus indicate where features such as ice-wedge casts may occur today (Gao, 2005; Morgan, 1972). The discrepancies highlighted between mapping in this paper and by Heginbottom et al. (1995) underscore the need for caution when interpreting outputs from previous models that have used the ground ice information as input parameters.

The modelling approach presented here is flexible and updateable, and the Geological Survey of Canada plans to make the most up-to-date iteration of ground ice maps for Canada available on GEOSCAN (https://geoscan.nrcan.gc.ca/, last access: 25 February 2019). The ground ice maps and derived surficial material data from this paper are available in the Supplement in GeoTIFF format. We look forward to further improving the mapping through future collaborations with, and feedback from, the Canadian permafrost community.

\section{Conclusions}

New modelling using a paleogeographic approach depicts the abundance of relict ice, segregated ice, and wedge ice in permafrost in Canada. The predictions are broadly consistent with observations from empirical studies. Relict ice is modelled in high abundance over $2 \%$ of the continuous 
permafrost zone and is restricted to thick glacigenic sediment that has remained in cold tundra environments during the Holocene. High segregated ice abundance is modelled over $3 \%$ of the continuous and $4 \%$ of the discontinuous permafrost zone in fine-grained marine and glacial lake sediments. High wedge ice abundance is modelled over $2 \%$ of the continuous permafrost zone, mainly on Banks and Victoria islands and the western Arctic coast. The distribution of high wedge ice abundance reflects the time available for ice-wedge cracking in tundra environments since terrain exposure following glaciation or submergence. The presented model outputs offer improved spatial detail and seemingly improved accuracy in several areas compared to previous ground ice mapping of Canada. This has potential implications for the validity of models that have used the Heginbottom et al. (1995) and Brown et al. (1997) ground ice mapping as input parameters. This study has identified the need for further compilation of ground ice information for the purposes of calibrating and validating small-scale ground ice models.

Data availability. The datasets are referred to in text (Sect. 3) and the links are in the reference list. Model outputs and the derived surficial material dataset are available in the Supplement.

Supplement. The supplement related to this article is available online at: https://doi.org/10.5194/tc-13-753-2019-supplement.

Author contributions. SAW conceived the modelling approach. SAW, HBO, and CD contributed to modifications to the models. $\mathrm{HBO}$ and SAW prepared the paper. CD operationalized the models in the geographic information system. CD and HBO produced cartographic outputs. All authors contributed edits to the paper. HBO revised the paper following review.

Competing interests. The authors declare that they have no conflict of interest.

Acknowledgements. The work was supported by Transport Canada and Natural Resources Canada's Postdoctoral Recruitment Program. The paper is Natural Resources Canada contribution no. 20180186 to the Climate Change Geoscience Program. The geographic information system support from Ryan Parker is gratefully acknowledged. The paper has benefitted from helpful comments and suggestions from Sharon Smith, Steve Kokelj, Dan Kerr, Rob Fraser, and Rod Smith. Discussions with Dan Kerr regarding the surficial geology of northern Canada are gratefully appreciated. We thank Mikhail Kanevskiy and Michel Allard for their helpful and constructive reviews and editor Christian Beer for his comments that helped improve the paper.
Edited by: Christian Beer

Reviewed by: Mikhail Kanevskiy and Michel Allard

\section{References}

Allard, M.: Interactive comment on "New ground ice maps for Canada using a paleogeographic modelling approach" by H. Brendan O'Neill et al., The Cryosphere Discuss., https://doi.org/10.5194/tc-2018-200-RC2, 2018.

Allard, M. and Kasper, J. N.: Temperature conditions for ice wedge cracking: field measurements from Salluit, northern Québec, in: Proceedings of the 7th International Permafrost Conference, Yellowknife, NT, 23-27 June 1998, Centre d'études nordiques, Université Laval, Québec City, Canada, 23-27 June 1998, 57, 5-11, 1998.

Allard, M. and Seguin, M. K.: The Holocene evolution of permafrost near the tree line, on the eastern coast of Hudson Bay (northern Quebec), Can. J. Earth Sci., 24, 2206-2222, https://doi.org/10.1139/e87-209, 1987.

Allard, M., Caron, S., and Bégin, Y.: Climatic and ecological controls on ice segregation and thermokarst: The case history of a permafrost plateau in Northern Quebec, Permafrost Periglac., 7, 207-227, https://doi.org/10.1002/(SICI)10991530(199609)7:3<207::AID-PPP219>3.0.CO;2-4, 1996.

Atlas of Canada: Average maximum snow depth, Reference Outline Map Series 6355, Scale 1:7,500,000, Natural Resources Canada, Ottawa, ON, Canada, 2010.

Bernard-Grand'Maison, C. and Pollard, W.: An estimate of ice wedge volume for a High Arctic polar desert environment, Fosheim Peninsula, Ellesmere Island, The Cryosphere, 12, 35893604, https://doi.org/10.5194/tc-12-3589-2018, 2018.

Bostock, H. S.: Physiographic regions of Canada, Map 1254A, Scale 1 : 5, 000, 000, Geological Survey of Canada, Ottawa, ON, Canada, 1970.

Brown, J., Ferrians, O. J., Heginbottom, J. A., and Melnikov, E. S.: Circum-Arctic map of permafrost and ground-ice conditions, Circum-Pacific Map Series CP-45, Scale 1 : 10,000,000, U.S. Geological Survey, Reston, VA, 1997.

Burn, C. R.: The development of near-surface ground ice during the Holocene at sites near Mayo, Yukon Territory, Canada, J. Quaternary Sci., 3, 31-38, https://doi.org/10.1002/jqs.3390030106, 1988.

Burn, C. R.: Implications for palaeoenvironmental reconstruction of recent ice-wedge development at Mayo, Yukon territory, Permafrost Periglac., 1, 3-14, https://doi.org/10.1002/ppp.3430010103, 1990.

Burn, C. R.: The response (1958-1997) of permafrost and nearsurface ground temperatures to forest fire, Takhini River valley, southern Yukon Territory, Can. J. Earth Sci., 35, 184-199, https://doi.org/10.1139/e97-105, 1998.

Burn, C. R.: Tundra lakes and permafrost, Richards Island, western Arctic coast, Canada, Can. J. Earth Sci., 39, 1281-1298, https://doi.org/10.1139/e02-035, 2002.

Burn, C. R.: The thermal regime of cryosols, in: Cryosols, Springer, Berlin, Heidelberg, 391-413, 2004.

Burn, C. R.: The geocryological bibliography of J. Ross Mackay (1915-2014), in: Proceedings, 68th Canadian Geotechnical Conference and 7th Canadian Permafrost Conference, Quebec City, 
QC, 21-23 September 2015, Canadian Geotechnical Society, Richmond, BC, Canada, 1-7, 2015.

Burn, C. R. and Kokelj, S. V.: The environment and permafrost of the Mackenzie Delta area, Permafrost Periglac., 20, 83-105, https://doi.org/10.1002/ppp.655, 2009.

Burn, C. R. and Lewkowicz, A. G.: Retrogressive thaw slumps, Can. Geogr., 34, 273-276, https://doi.org/10.1111/j.15410064.1990.tb01092.x, 1990.

Calmels, F., Allard, M., and Delisle, G.: Development and decay of a lithalsa in Northern Québec: A geomorphological history, Geomorphology, 97, 287-299, https://doi.org/10.1016/j.geomorph.2007.08.013, 2008a.

Calmels, F., Delisle, G., and Allard, M.: Internal structure and the thermal and hydrological regime of a typical lithalsa: significance for permafrost growth and decay, Can. J. Earth Sci., 45, 31-43, https://doi.org/10.1139/e07-068, 2008b.

Chadburn, S. E., Burke, E. J., Cox, P. M., Friedlingstein, P., Hugelius, G., and Westermann, S.: An observationbased constraint on permafrost loss as a function of global warming, Nat. Clim. Change, 7, 340-344, https://doi.org/10.1038/nclimate3262, 2017.

Chamberlain, E. J.: Frost susceptibility of soil, review of index tests, CRREL-81-2, Cold Regions Research and Engineering Laboratory, Hanover, NH, USA, 1981.

Cheng, G.: The mechanism of repeated-segregation for the formation of thick layered ground ice, Cold Reg. Sci. Technol., 8, 5766, https://doi.org/10.1016/0165-232X(83)90017-4, 1983.

Coulombe, S., Fortier, D., Lacelle, D., Kanevskiy, M., and Shur, Y.: Origin, burial and preservation of late Pleistocene-age glacier ice in Arctic permafrost (Bylot Island, NU, Canada), The Cryosphere, 13, 97-111, https://doi.org/10.5194/tc-13-97-2019, 2019.

Couture, N. and Pollard, W. H.: An assessment of ground ice volume near Eureka, Northwest Territories, in: Proceedings of the 7th International Permafrost Conference, Yellowknife, NT, 2327 June 1998, Yellowknife, NT, Centre d'études nordiques, Université Laval, Québec City, Canada, 195-200, 1998.

Couture, R. and Riopel, S.: Landslide inventory along a proposed gas pipeline between Inuvik and Tulita, Mackenzie Valley, Northwest Territories, Open File 5740, Geological Survey of Canada, Ottawa, ON, Canada, 2008.

Dallimore, A., Schröder-Adams, C. J., and Dallimore, S. R.: Holocene environmental history of thermokarst lakes on Richards Island, Northwest Territories, Canada: theocamoebians as paleolimnological indicators, J. Paleolimnol., 23, 261-283, 2000.

Dallimore, S. R. and Wolfe, S. A.: Massive ground ice associated with glaciofluvial sediments, Richards Island, NWT, Canada, in: Proceedings of the 5th International Conference on Permafrost, Trondheim, Norway, 2-5 August 1988, Tapir Publishers, Trondheim, Norway, 132-138, 1988.

Deblonde, C., Cocking, R. B., Kerr, D. E., Campbell, J. E., Eagles, S., Everett, D., Huntley, D. H., Inglis, E., Parent, M., Plouffe, A., Robertson, L., Smith, I. R., and Weatherston, A.: Surficial Data Model: the science language of the integrated Geological Survey of Canada data model for surficial geology maps, Open File 8236, Geological Survey of Canada, Ottawa, ON, Canada, 2018.
De Pascale, G. P., Pollard, W. H., and Williams, K. K.: Geophysical mapping of ground ice using a combination of capacitive coupled resistivity and ground-penetrating radar, Northwest Territories, Canada, J. Geophys. Res., 113, F02S90, https://doi.org/10.1029/2006JF000585, 2008.

Dyke, A. S. and Savelle, J. M.: Major end moraines of Younger Dryas age on Wollaston Peninsula, Victoria Island, Canadian Arctic: implications for paleoclimate and for formation of hummocky moraine, Can. J. Earth Sci., 37, 601-619, https://doi.org/10.1139/e99-118, 2000.

Dyke, A. S., Moore, A., and Robertson, L.: Deglaciation of North America, Open File 1574, Geological Survey of Canada, Ottawa, ON, Canada, 2003.

Dyke, A. S., Giroux, D., and Robertson, L.: Paleovegetation maps of northern North America, 18000 to 1000 BP, Open File 4682, Geological Survey of Canada, Ottawa, ON, Canada, 2004.

Essery, R. and Pomeroy, J.: Vegetation and topographic control of wind-blown snow distributions in distributed and aggregated simulations for an Arctic tundra basin, J. Hydrometeorol., 5, 735-744, https://doi.org/10.1175/15257541(2004)005<0735:VATCOW>2.0.CO;2, 2004.

Evans, D. J. A.: Glacial Landsystems, Arnold, London, UK, 2003.

Evans, D. J. A.: Controlled moraines: origins, characteristics and palaeoglaciological implications, Quaternary Sci. Rev., 28, 183208, https://doi.org/10.1016/j.quascirev.2008.10.024, 2009.

Fortier, D. and Allard, M.: Late Holocene syngenetic icewedge polygons development, Bylot Island, Canadian Arctic Archipelago, Can. J. Earth Sci., 41, 997-1012, https://doi.org/10.1139/e04-031, 2004.

Fortier, D. and Allard, M.: Frost-cracking conditions, Bylot Island, eastern Canadian Arctic archipelago, Permafrost Periglac., 16, 145-161, https://doi.org/10.1002/ppp.504, 2005.

Fortier, D., Allard, M., and Shur, Y.: Observation of rapid drainage system development by thermal erosion of ice wedges on Bylot Island, Canadian Arctic Archipelago, Permafrost Periglac., 18, 229-243, https://doi.org/10.1002/ppp.595, 2007.

Fortier, D., Strauss, J., Sliger, M., Calmels, F., Froese, D., and Shur, Y.: Pleistocene yedoma in south-western Yukon (Canada): a remnant of Eastern Beringia?, Chamonix Mont-Blanc, 1-2, 2018.

Fraser, R., Kokelj, S. V., Lantz, T. C., McFarlane-Winchester, M., Olthof, I., and Lacelle, D.: Climate sensitivity of High Arctic permafrost terrain demonstrated by widespread icewedge thermokarst on Banks Island, Remote Sens., 10, 954, https://doi.org/10.3390/rs10060954, 2018.

Fraser, T. A. and Burn, C. R.: On the nature and origin of "muck" deposits in the Klondike area, Yukon Territory, Can. J. Earth Sci., 34, 1333-1344, https://doi.org/10.1139/e17-106, 1997.

French, H. and Shur, Y.: The principles of cryostratigraphy, Earth-Sci. Rev., 101, 190-206, https://doi.org/10.1016/j.earscirev.2010.04.002, 2010.

French, H. M.: Active thermokarst processes, Eastern Banks Island, Western Canadian Arctic, Can. J. Earth Sci., 11, 785-794, https://doi.org/10.1139/e74-078, 1974.

French, H. M. and Harry, D. G.: Nature and origin of ground ice, Sandhills Moraine, southwest Banks Island, Western Canadian Arctic, J. Quaternary Sci., 3, 19-30, https://doi.org/10.1002/jqs.3390030105, 1988.

French, H. M. and Harry, D. G.: Observations on buried glacier ice and massive segregated ice, western Arc- 
tic coast, Canada, Permafrost Periglac., 1, 31-43, https://doi.org/10.1002/ppp.3430010105, 1990.

Fritz, M., Wetterich, S., Meyer, H., Schirrmeister, L., Lantuit, H., and Pollard, W. H.: Origin and characteristics of massive ground ice on Herschel Island (western Canadian Arctic) as revealed by stable water isotope and Hydrochemical signatures, Permafrost Periglac., 22, 26-38, https://doi.org/10.1002/ppp.714, 2011.

Fulton, R. J.: Quaternary geology of the Canadian interior plains, in: Quaternary Geology of Canada and Greenland, edited by: Fulton, R. J., Geological Survey of Canada, Ottawa, ON, Canada, Geology of Canada Series no. 1, 1989.

Fulton, R. J.: Surficial materials of Canada, "A" Series Map 1880A, Scale $1: 5,000,000$, Natural Resources Canada, Ottawa, ON, Canada, 1995.

Gao, C.: Ice-wedge casts in Late Wisconsinan glaciofluvial deposits, southern Ontario, Canada, Can. J. Earth Sci., 42, $2117-$ 2126, https://doi.org/10.1139/e05-072, 2005.

Geological Survey of Canada: Surficial geology of Canada, Canadian Geoscience Map 195, Scale 1:5,000,000, Natural Resources Canada, Ottawa, ON, Canada, 2014.

Gilbert, G. L., Kanevskiy, M., and Murton, J. B.: Recent Advances (2008-2015) in the Study of Ground Ice and Cryostratigraphy, Permafrost Periglac., 27, 377-389, https://doi.org/10.1002/ppp.1912, 2016.

Gilbert, G. L., O’Neill, H. B., Nemec, W., Thiel, C., Christiansen, H. H., and Buylaert, J.-P.: Late Quaternary sedimentation and permafrost development in a Svalbard fjordvalley, Norwegian high Arctic, Sedimentology, 65, 2531-2558, https://doi.org/10.1111/sed.12476, 2018.

Gruber, S.: Derivation and analysis of a high-resolution estimate of global permafrost zonation, The Cryosphere, 6, 221-233, https://doi.org/10.5194/tc-6-221-2012, 2012.

Hamilton, T. D., Ager, T. A., and Robinson, S. W.: Late Holocene ice wedges near Fairbanks, Alaska, USA: environmental setting and history of growth, Arctic Alpine Res., 15, 157-158, 1983.

Heginbottom, J. A.: Permafrost mapping: a review, Prog. Phys. Geog., 26, 623-642, https://doi.org/10.1191/0309133302pp355ra, 2002.

Heginbottom, J. A. and Dubreuil, M.-A.: A new permafrost and ground ice map for the National Atlas of Canada, in: Proceedings of the 6th International Permafrost Conference, South China University of Technology Press, Beijing, China, 1, 255-260, 1993.

Heginbottom, J. A., Dubreuil, M.-A., and Harker, P. A. C.: Permafrost - Canada, National Atlas of Canada MCR 4177, Scale $1: 7,500,000$, Department of Energy, Mines and Resources Canada, 1995.

Hinkel, K. M., Doolittle, J. A., Bockheim, J. G., Nelson, F. E., Paetzold, R., Kimble, J. M., and Travis, R.: Detection of subsurface permafrost features with ground-penetrating radar, Barrow, Alaska, Permafrost Periglac., 12, 179-190, https://doi.org/10.1002/ppp.369, 2001.

Hopkins, D. M.: Thaw lakes and thaw sinks in the Imuruk Lake area, Seward Peninsula, Alaska, J. Geol., 57, 119-131, https://doi.org/10.1086/625591, 1949.

Johnson, E. A.: Fire recurrence in the subarctic and its implications for vegetation composition, Can. J. Bot., 57, 1374-1379, https://doi.org/10.1139/b79-171, 1979.
Jones, B. M., Grosse, G., Hinkel, K. M., Arp, C. D., Walker, S., Beck, R. A., and Galloway, J. P.: Assessment of pingo distribution and morphometry using an IfSAR derived digital surface model, western Arctic Coastal Plain, Northern Alaska, Geomorphology, 138, 1-14, https://doi.org/10.1016/j.geomorph.2011.08.007, 2012.

Jorgenson, M. T., Shur, Y. L., and Pullman, E. R.: Abrupt increase in permafrost degradation in Arctic Alaska, Geophys. Res. Lett., 33, L02503, https://doi.org/10.1029/2005GL024960, 2006.

Jorgenson, M. T., Yoshikawa, K., Kanevskiy, M., Shur, Y. L., Romanovsky, V. E., Marchenko, S., Grosse, G., Brown, J., and Jones, B.: Permafrost characteristics of Alaska, in Proceedings of the 9th International Conference on Permafrost, Fairbanks, Alaska, 28 June-3 July 2008, University of Alaska, Fairbanks, USA, 29, 121-122, 2008.

Jorgenson, M. T., Kanevskiy, M., Shur, Y., Moskalenko, N., Brown, D. R. N., Wickland, K., Striegl, R., and Koch, J.: Role of ground ice dynamics and ecological feedbacks in recent ice wedge degradation and stabilization, J. Geophys. Res.-Earth, 120, 2280-2297, https://doi.org/10.1002/2015JF003602, 2015.

Kääb, A.: Remote sensing of permafrost-related problems and hazards, Permafrost Periglac., 19, 107-136, https://doi.org/10.1002/ppp.619, 2008.

Kanevskiy, M., Shur, Y., Fortier, D., Jorgenson, M. T., and Stephani, E.: Cryostratigraphy of late Pleistocene syngenetic permafrost (yedoma) in northern Alaska, Itkillik River exposure, Quaternary Res., 75, 584-596, https://doi.org/10.1016/j.yqres.2010.12.003, 2011.

Kanevskiy, M., Shur, Y., Jorgenson, M. T., Ping, C.-L., Michaelson, G. J., Fortier, D., Stephani, E., Dillon, M., and Tumskoy, V.: Ground ice in the upper permafrost of the Beaufort Sea coast of Alaska, Cold Reg. Sci. Technol., 85, 56-70, https://doi.org/10.1016/j.coldregions.2012.08.002, 2013.

Kneisel, C., Hauck, C., Fortier, R., and Moorman, B.: Advances in geophysical methods for permafrost investigations, Permafrost Periglac., 19, 157-178, https://doi.org/10.1002/ppp.616, 2008.

Kokelj, S. V. and Burn, C. R.: Ground ice and soluble cations in near-surface permafrost, Inuvik, Northwest Territories, Canada, Permafrost Periglac., 14, 275-289, https://doi.org/10.1002/ppp.458, 2003.

Kokelj, S. V. and Burn, C. R.: Near-surface ground ice in sediments of the Mackenzie Delta, Northwest Territories, Canada, Permafrost Periglac., 16, 291-303, https://doi.org/10.1002/ppp.537, 2005.

Kokelj, S. V. and Jorgenson, M. T.: Advances in Thermokarst Research: Recent Advances in Research Investigating Thermokarst Processes, Permafrost Periglac., 24, 108-119, https://doi.org/10.1002/ppp.1779, 2013.

Kokelj, S. V., Pisaric, M. F., and Burn, C. R.: Cessation of ice-wedge development during the 20th century in spruce forests of eastern Mackenzie Delta, Northwest Territories, Canada, Can. J. Earth Sci., 44, 1503-1515, https://doi.org/10.1139/e07-035, 2007a.

Kokelj, S. V., Burn, C. R., and Tarnocai, C.: The structure and dynamics of earth hummocks in the subarctic forest near Inuvik, Northwest Territories, Canada, Arct. Antarct. Alp. Res., 39, 99109, 2007b.

Kokelj, S. V., Lantz, T. C., Wolfe, S. A., Kanigan, J. C., Morse, P. D., Coutts, R., Molina-Giraldo, N., and Burn, C. R.: Distribution and activity of ice wedges across the forest-tundra transition, 
western Arctic Canada, J. Geophys. Res.-Earth, 119, 2032-2047, https://doi.org/10.1002/2014JF003085, 2014.

Kokelj, S. V., Tunnicliffe, J., Lacelle, D., Lantz, T. C., Chin, K. S., and Fraser, R.: Increased precipitation drives mega slump development and destabilization of ice-rich permafrost terrain, northwestern Canada, Global Planet. Change, 129, 56-68, https://doi.org/10.1016/j.gloplacha.2015.02.008, 2015.

Kokelj, S. V., Lantz, T. C., Tunnicliffe, J., Segal, R., and Lacelle, D.: Climate-driven thaw of permafrost preserved glacial landscapes, northwestern Canada, Geology, 45, 371-374, https://doi.org/10.1130/G38626.1, 2017.

Konrad, J. M.: Theoretical modelling of massive icy beds, in: Proceedings of the 5th Canadian Permafrost Conference, Centre d'études nordiques, Université Laval, Québec City, Canada, Collection Nordicana, 54, 31-35, 1990.

Kotler, E. and Burn, C. R.: Cryostratigraphy of the Klondike "muck" deposits, west-central Yukon Territory, Can. J. Earth Sci., 37, 849-861, https://doi.org/10.1139/e00-013, 2000.

Kuhry, P.: Palsa and peat plateau development in the Hudson Bay Lowlands, Canada: timing, pathways and causes, Boreas, 37, 316-327, https://doi.org/10.1111/j.1502-3885.2007.00022.x, 2008.

Laberge, M.-J. and Payette, S.: Long-Term Monitoring of Permafrost Change in a Palsa Peatland in Northern Quebec, Canada: 1983-1993, Arctic Alpine Res., 27, 167-171, https://doi.org/10.2307/1551898, 1995.

Labrecque, S., Lacelle, D., Duguay, C., Lauriol, B., and Hawkins, J.: Contemporary (1951-2001) evolution of lakes in the Old Crow Basin, Northern Yukon, Canada: Remote sensing, numerical modeling, and stable isotope analysis, Arctic, 62, 225-238, 2009.

Lacelle, D., Brooker, A., Fraser, R. H., and Kokelj, S. V.: Distribution and growth of thaw slumps in the Richardson MountainsPeel Plateau region, northwestern Canada, Geomorphology, 235, 40-51, https://doi.org/10.1016/j.geomorph.2015.01.024, 2015.

Lachenbruch, A. H.: Mechanics of thermal contraction cracks and ice-wedge polygons in permafrost, Geological Society of America, Special Papers Vol. 70, https://doi.org/10.1130/SPE70, 1962.

Lakeman, T. R. and England, J. H.: Paleoglaciological insights from the age and morphology of the Jesse moraine belt, western Canadian Arctic, Quaternary Sci. Rev., 47, 82-100, https://doi.org/10.1016/j.quascirev.2012.04.018, 2012.

Lakeman, T. R. and England, J. H.: Late Wisconsinan glaciation and postglacial relative sea-level change on western Banks Island, Canadian Arctic Archipelago, Quaternary Res., 80, 99112, https://doi.org/10.1016/j.yqres.2013.02.001, 2013.

Lantz, T. C. and Kokelj, S. V.: Increasing rates of retrogressive thaw slump activity in the Mackenzie Delta region, N.W.T., Canada, Geophys. Res. Lett., 35, L06502, https://doi.org/10.1029/2007GL032433, 2008.

Larsen, C. P. S.: Spatial and temporal variations in boreal forest fire frequency in northern Alberta, J. Biogeogr., 24, 663-673, https://doi.org/10.1111/j.1365-2699.1997.tb00076.x, 1997.

Lewkowicz, A. G.: Dynamics of active-layer detachment failures, Fosheim Peninsula, Ellesmere Island, Nunavut, Canada, Permafrost Periglac., 18, 89-103, https://doi.org/10.1002/ppp.578, 2007.

Liljedahl, A. K., Boike, J., Daanen, R. P., Fedorov, A. N., Frost, G. V., Grosse, G., Hinzman, L. D., Iijma, Y., Jorgenson, J. C.,
Matveyeva, N., Necsoiu, M., Raynolds, M. K., Romanovsky, V. E., Schulla, J., Tape, K. D., Walker, D. A., Wilson, C. J., Yabuki, H., and Zona, D.: Pan-Arctic ice-wedge degradation in warming permafrost and its influence on tundra hydrology, Nat. Geosci., 9, 312-318, https://doi.org/10.1038/ngeo2674, 2016.

Liston, G. E., Mcfadden, J. P., Sturm, M., and Pielke, R. A.: Modelled changes in arctic tundra snow, energy and moisture fluxes due to increased shrubs, Global Change Biol., 8, 17-32, https://doi.org/10.1046/j.1354-1013.2001.00416.x, 2002.

Lorrain, R. D. and Demeur, P.: Isotopic evidence for relic Pleistocene glacier ice on Victoria Island, Canadian Arctic Archipelago, Arctic Alpine Res., 17, 89-98, https://doi.org/10.2307/1550964, 1985.

Mackay, J. R.: The Mackenzie Delta area, Memoir 8, Geographical Branch, Department of Mines and Technical Surveys, Ottawa, ON, Canada, 1963.

Mackay, J. R.: The origin of massive icy beds in permafrost, western Arctic coast, Canada, Can. J. Earth Sci., 8, 397-422, https://doi.org/10.1139/e71-043, 1971.

Mackay, J. R.: The growth of pingos, western Arctic coast, Canada, Can. J. Earth Sci., 10, 979-1004, https://doi.org/10.1139/e73086, 1973.

Mackay, J. R.: Ice-wedge cracks, Garry Island, Northwest Territories, Can. J. Earth Sci., 11, 1366-1383, https://doi.org/10.1139/e74-133, 1974.

Mackay, J. R.: Downward water movement into frozen ground, western arctic coast, Canada, Can. J. Earth Sci., 20, 120-134, https://doi.org/10.1139/e83-012, 1983.

Mackay, J. R.: The first 7 years (1978-1985) of ice wedge growth, Illisarvik experimental drained lake site, western Arctic coast, Can. J. Earth Sci., 23, 1782-1795, https://doi.org/10.1139/e86164, 1986.

Mackay, J. R.: The frequency of ice-wedge cracking (1967-1987) at Garry Island, western Arctic coast, Canada, Can. J. Earth Sci., 29, 236-248, https://doi.org/10.1139/e92-022, 1992.

Mackay, J. R.: Active layer changes (1968 to 1993) following the forest-tundra fire near Inuvik, N.W.T., Canada, Arctic Alpine Res., 27, 323-336, https://doi.org/10.2307/1552025, 1995.

Mackay, J. R. and Burn, C. R.: The first 20 years (1978-1979 to 1998-1999) of active-layer development, Illisarvik experimental drained lake site, western Arctic coast, Canada, Can. J. Earth Sci., 39, 1657-1674, https://doi.org/10.1139/e02-068, 2002a.

Mackay, J. R. and Burn, C. R.: The first 20 years (1978-1979 to 1998-1999) of ice-wedge growth at the Illisarvik experimental drained lake site, western Arctic coast, Canada, Can. J. Earth Sci., 39, 95-111, https://doi.org/10.1139/e01-048, 2002b.

Mackay, J. R. and Dallimore, S. R.: Massive ice of the Tuktoyaktuk area, western Arctic coast, Canada, Can. J. Earth Sci., 29, 12351249, https://doi.org/10.1139/e92-099, 1992.

Martini, I. P. and Morrison, R. I. G.: Coasts of Foxe Basin, Arctic Canada, Geological Society, London, Special Publications, 388, 165-198, https://doi.org/10.1144/SP388.14, 2014.

Matthews, J. V., Schweger, C. E., and Janssens, J. A.: The last (KoyYukon) interglaciation in the northern Yukon: evidence from unit 4 at Ch'ijee's Bluff, Bluefish Basin, Geogr. Phys. Quatern., 44, 341-362, https://doi.org/10.7202/032835ar, 1990.

Miller, R. D.: Freezing and heaving of saturated and unsaturated soils, Highway Research Record 393, U.S. National Research Council, Washington, D.C., 1972. 
Morgan, A. V.: Late Wisconsinan ice-wedge polygons near Kitchener, Ontario, Canada, Can. J. Earth Sci., 9, 607-617, https://doi.org/10.1139/e72-052, 1972.

Morse, P. D., Burn, C. R., and Kokelj, S. V.: Near-surface ground-ice distribution, Kendall Island Bird Sanctuary, western Arctic coast, Canada, Permafrost Periglac., 20, 155-171, https://doi.org/10.1002/ppp.650, 2009.

Murton, J.: Thermokarst sediments and sedimentary structures, Tuktoyaktuk Coastlands, western Arctic Canada, Global Planet. Change, 28, 175-192, https://doi.org/10.1016/S09218181(00)00072-2, 2001.

Murton, J. B.: Ground-ice stratigraphy and formation at North Head, Tuktoyaktuk Coastlands, western Arctic Canada: a product of glacier-permafrost interactions, Permafrost Periglac., 16, 31-50, https://doi.org/10.1002/ppp.513, 2005.

Murton, J. B., Whiteman, C. A., Waller, R. I., Pollard, W. H., Clark, I. D., and Dallimore, S. R.: Basal ice facies and supraglacial melt-out till of the Laurentide Ice Sheet, Tuktoyaktuk Coastlands, western Arctic Canada, Quaternary Sci. Rev., 24, 681708, https://doi.org/10.1016/j.quascirev.2004.06.008, 2005.

Nelson, F. E., Anisimov, O. A., and Shiklomanov, N. I.: Subsidence risk from thawing permafrost, Nature, 410, 889-890, https://doi.org/10.1038/35073746, 2001.

Olefeldt, D., Goswami, S., Grosse, G., Hayes, D., Hugelius, G., Kuhry, P., McGuire, A. D., Romanovsky, V. E., Sannel, A. B. K., Schuur, E. A. G., and Turetsky, M. R.: Circumpolar distribution and carbon storage of thermokarst landscapes, Nat. Commun., 7, 13043, https://doi.org/10.1038/ncomms13043, 2016.

O’Neill, H. B. and Burn, C. R.: Physical and temporal factors controlling the development of near-surface ground ice at Illisarvik, western Arctic coast, Canada, Can. J. Earth Sci., 49, 1096-1110, https://doi.org/10.1139/e2012-043, 2012.

O'Neill, H. B. and Christiansen, H. H.: Detection of ice wedge cracking in permafrost using miniature accelerometers, J. Geophys. Res.-Earth, 123, 642-657, https://doi.org/10.1002/2017JF004343, 2018.

O’Neill, H. B., Burn, C. R., Kokelj, S. V., and Lantz, T. C.: "Warm" tundra: Atmospheric and near-surface ground temperature inversions across an alpine treeline in continuous permafrost, western Arctic, Canada, Permafrost Periglac., 26, 103118, https://doi.org/10.1002/ppp.1838, 2015.

Opel, T., Meyer, H., Wetterich, S., Laepple, T., Dereviagin, A., and Murton, J.: Ice wedges as archives of winter paleoclimate: A review, Permafrost Periglac., 29, 199-209, https://doi.org/10.1002/ppp.1980, 2018.

Overton, S.: A strategy of model construction, in: Ecosystem Modeling in Theory and Practice: An Introduction with Case Histories, John Wiley \& Sons, New York, USA, 1977.

Palmer, M. J., Burn, C. R., and Kokelj, S. V.: Factors influencing permafrost temperatures across tree line in the uplands east of the Mackenzie Delta, 2004-2010, Can. J. Earth Sci., 49, 877894, https://doi.org/10.1139/e2012-002, 2012.

Payette, S.: Accelerated thawing of subarctic peatland permafrost over the last 50 years, Geophys. Res. Lett., 31, L18208, https://doi.org/10.1029/2004GL020358, 2004.

Payette, S., Morneau, C., Sirois, L., and Desponts, M.: Recent fire history of the northern Quebec biomes, Ecology, 70, 656-673, https://doi.org/10.2307/1940217, 1989.
Pollard, W. H.: Observations On Massive Ground Ice On Fosheim Peninsula, Ellesmere Island, Northwest Territories, Current Research, Geological Survey of Canada, Ottawa, ON, Canada, 1991.

Pollard, W. H.: Distribution and characterization of ground ice on Fosheim Peninsula, Ellesmere Island, Nunavut, in: Environmental response to climate change in the Canadian High Arctic, edited by: Garneau, M. and Alt, B. T., Geological Survey of Canada, Ottawa, ON, Canada, Bulletin 529, 207-233, 2000.

Pollard, W. H. and French, H. M.: A first approximation of the volume of ground ice, Richards Island, Pleistocene Mackenzie delta, Northwest Territories, Canada, Can. Geotech. J., 17, 509-516, https://doi.org/10.1139/t80-059, 1980.

Prest, V. K., Grant, D. R., and Rampton, V. N.: Glacial map of Canada, "A" Series Map 1253A, Scale 1: 5, 000, 000, Geological Survey of Canada, Ottawa, ON, Canada, 1968.

Rampton, V. N.: Origin of massive ground ice on Tuktoyaktuk Peninsula, Northwest Territories, Canada: a review of stratigraphic and geomorphic evidence, in: Proceedings of the 5th International Conference on Permafrost, Trondheim, Norway, 2-5 August 1988, Tapir Publishers, Trondheim, Norway, 1, 850-855, 1988a.

Rampton, V. N.: Quaternary Geology of the Tuktoyaktuk Coastlands, Northwest Territories, Memoir 423, Geological Survey of Canada, Ottawa, ON, Canada, 1988 b.

Raynolds, M. K., Walker, D. A., Ambrosius, K. J., Brown, J., Everett, K. R., Kanevskiy, M., Kofinas, G. P., Romanovsky, V. E., Shur, Y., and Webber, P. J.: Cumulative geoecological effects of 62 years of infrastructure and climate change in ice-rich permafrost landscapes, Prudhoe Bay Oilfield, Alaska, Global Change Biol., 20, 1211-1224, https://doi.org/10.1111/gcb.12500, 2014.

Riseborough, D., Shiklomanov, N., Etzelmüller, B., Gruber, S., and Marchenko, S.: Recent advances in permafrost modelling, Permafrost Periglac., 19, 137-156, https://doi.org/10.1002/ppp.615, 2008.

Robinson, S. D. and Pollard, W. H.: Massive ground ice within Eureka Sound bedrock, Ellesmere Island, Canada, in: Proceedings of the 7th International Permafrost Conference, Yellowknife, NT, 23-27 June 1998, Collection Nordicana, Centre d'études nordiques, Université Laval, Québec City, Canada, 57, 949-954, 1998.

Roy-Leveillée, P. and Burn, C. R.: Geometry of oriented lakes in Old Crow Flats, northern Yukon, in: Proceedings, 68th Canadian Geotechnical Conference and 7th Canadian Permafrost Conference Quebec City, QC, 21-23 September 2015, Canadian Geotechnical Society, Richmond, BC, Canada, 1-8, 2015.

Roy-Leveillée, P. and Burn, C. R.: Near-shore talik development beneath shallow water in expanding thermokarst lakes, Old Crow Flats, Yukon, J. Geophys. Res.-Earth, 122, 1070-1089, https://doi.org/10.1002/2016JF004022, 2017.

Rudy, A. C. A., Lamoureux, S. F., Kokelj, S. V., Smith, I. R., and England, J. H.: Accelerating Thermokarst Transforms Ice-Cored Terrain Triggering a Downstream Cascade to the Ocean: Thermokarst Triggers a Cascade to Ocean, Geophys. Res. Lett., 44, 11080-11087, https://doi.org/10.1002/2017GL074912, 2017. 
Rykiel, E. J.: Testing ecological models: the meaning of validation, Ecol. Model., 90, 229-244, https://doi.org/10.1016/03043800(95)00152-2, 1996.

Segal, R. A., Kokelj, S. V., Lantz, T. C., Pierce, K. L., Durkee, K., Gervais, S., Mahon, E., Snijders, M., Buysse, J., and Schwarz, S.: Mapping of terrain affected by retrogressive thaw slumping in Northwestern Canada, Open Report 2016-023, Northwest Territories Geological Survey, 2016.

Shur, Y., Hinkel, K. M., and Nelson, F. E.: The transient layer: implications for geocryology and climate-change science, Permafrost Periglac., 16, 5-17, https://doi.org/10.1002/ppp.518, 2005.

Shur, Y. L. and Jorgenson, M. T.: Patterns of permafrost formation and degradation in relation to climate and ecosystems, Permafrost Periglac., 18, 7-19, https://doi.org/10.1002/ppp.582, 2007.

Silver, N.: The signal and the noise: why so many predictions failbut some don't, Penguin Press, New York, USA, 2012.

Smith, S. L. and Burgess, M. M.: Sensitivity of permafrost to climate warming in Canada, Bulletin 579, Geological Survey of Canada, Ottawa, ON, Canada, 2004.

Smith, S. L., Romanovsky, V. E., Lewkowicz, A. G., Burn, C. R., Allard, M., Clow, G. D., Yoshikawa, K., and Throop, J.: Thermal state of permafrost in North America: a contribution to the international polar year, Permafrost Periglac., 21, 117-135, https://doi.org/10.1002/ppp.690, 2010.

Stevens, C. W., Kerr, D. E., Wolfe, S. A., and Eagles, S.: Predictive surficial geology, Yellowknife and Hearne Lake, Northwest Territories, NTS 85-J and NTS 85-I, Canadian Geoscience Map 200, Scale $1: 125$ : 000, Natural Resources Canada, Ottawa, ON, Canada, 2017.

St-Onge, D. A. and McMartin, I.: Quaternary geology of the Inman River area, Northwest Territories, Bulletin 446, Geological Survey of Canada, Ottawa, ON, Canada, 1995.

Sturm, M., Holmgren, J., McFadden, J. P., Liston, G. E., Chapin, F. S., and Racine, C. H.: Snow-Shrub Interactions in Arctic Tundra: A Hypothesis with Climatic Implications, J. Climate, 14, 336-344, https://doi.org/10.1175/15200442(2001)014<0336:SSIIAT>2.0.CO;2, 2001.
Taber, S.: Frost Heaving, J. Geol., 37, 428-461, https://doi.org/10.1086/623637, 1929.

Tarnocai, C., Kettles, I. M., and Lacelle, B.: Peatlands of Canada, Open File 6561, Geological Survey of Canada, Ottawa, ON, Canada, 2011.

Turner, K. W., Wolfe, B. B., Edwards, T. W. D., Lantz, T. C., Hall, R. I., and Larocque, G.: Controls on water balance of shallow thermokarst lakes and their relations with catchment characteristics: a multi-year, landscape-scale assessment based on water isotope tracers and remote sensing in Old Crow Flats, Yukon (Canada), Global Change Biol., 20, 1585-1603, https://doi.org/10.1111/gcb.12465, 2014.

Ulrich, M., Grosse, G., Strauss, J., and Schirrmeister, L.: Quantifying Wedge-Ice Volumes in Yedoma and Thermokarst Basin Deposits: Wedge-Ice Volume Calculation in Yedoma and Thermokarst Basin Deposits, Permafrost Periglac., 25, 151-161, https://doi.org/10.1002/ppp.1810, 2014.

Viereck, L. A.: The effects of fire in black spruce ecosystemsof Alaska and northern Canada, in: The role of fire in northern circumpolar ecosystems, Wiley, New York, USA, 210-220, 1983.

Wheeler, J. O., Hoffman, P. F., Card, K. D., Davidson, A., Sanford, B. V., Okulitch, A. V., and Roest, W. R.: Geological map of Canada, "A" Series Map 1860A, Scale 1 : 5, 000, 000, Natural Resources Canada, Ottawa, ON, Canada, 1996.

Wolfe, S. A., Stevens, C. W., Gaanderse, A. J., and Oldenborger, G. A.: Lithalsa distribution, morphology and landscape associations in the Great Slave Lowland, Northwest Territories, Canada, Geomorphology, 204, 302-313, https://doi.org/10.1016/j.geomorph.2013.08.014, 2014.

Wolfe, S. A., Kerr, D. E., and Morse, P. D.: Slave Geological Province: An Archetype of Glaciated Shield Terrain, in: Landscapes and Landforms of Western Canada, edited by: Slaymaker, O., Springer, Switzerland, 77-86, 2017.

Zoltai, S. C.: Palsas and Peat Plateaus in Central Manitoba and Saskatchewan, Can. J. Forest Res., 2, 291-302, https://doi.org/10.1139/x72-046, 1972.

Zoltai, S. C. and Tarnocai, C.: Properties of A Wooded Palsa in Northern Manitoba, Arctic Alpine Res., 3, 115-129, 1971. 